TRANS · núm. 25.2021

DOSIER $\cdot 61-88$

La historia de la traducción en América en el siglo XVI tiene estrecha intimidad con la construcción de un imperio colonial. En cartas, crónicas, relaciones, diarios, autobiografías, historias, narrativas diversas, páginas científicas, documentos administrativos y leyes es casi imposible aislar los fragmentos que aluden a intérpretes y traductores de los relatos estremecedores, de las operaciones políticas y diplomáticas que tuvieron como fin el lucro mediante la explotación de los indígenas y la esclavitud. La traducción en su forma más generalizada, a través de lenguas, nahuatlatos, intérpretes, sirvió para el avasallamiento de los sometidos. Paradójicamente también existió lo contrario: textos precoces que, en el amplio escenario de la evangelización, conservaron formas verbales y estéticas de las civilizaciones destinadas a desaparecer.

PALABRAS CLAVE: América, siglo XVI, intérpretes, lenguaje de señas, catecismos, códices, traducción iconográfica, censura de libros.

\title{
La traducción en América en el siglo XVI
}

\author{
Anna Gargatagl \\ Universidad Autónoma de Barcelona
}

\section{Translation in America in the $16^{\text {th }}$ century}

The history of translation in America in the $16^{\text {th }}$ century is closely related to the construction of a colonial empire. In letters, chronicles, accounts, diaries, autobiographies, stories, diverse narratives, scientific texts, administrative documents and laws, it is almost impossible to isolate the fragments alluding to the interpreters and translators from heart-rending accounts of the political and diplomatic operations designed to obtain profit by exploiting and enslaving the indigenous peoples. In its most generalised form, translation between languages by nahuatlatos, or interpreters, was used to subjugate the oppressed. Paradoxically, the opposite is also found -there were early texts which, in the broad framework of evangelization, preserved verbal and aesthetic forms of the civilizations that were destined to disappear.

KEY WORDS: America, $16^{\text {th }}$ century, interpreters, sign language, catechisms, codices, Iconographic translation, censorship of books.

\footnotetext{
* No desearía que la minuciosa y excelente revisión de Rosana Bazaga Sanz y Carmen Velasco Rengel de este trabajo quedara en el anonimato. Las acompañará siempre mi agradecimiento.
} 


\section{INTRODUCCIÓN}

En América, a lo largo del siglo XVI, doscientos cincuenta mil españoles ${ }^{1}$ — navegantes, aventureros, soldadesca, analfabetos, letrados, funcionarios coloniales, comerciantes, artesanos, artistas, figuras del clero, religiosos con formación lingüística, un número creciente de mujeres-, enfrentaron la multiplicidad lingüística del continente. Las ciento cincuenta familias de lenguas amerindias, aglutinantes y desconocidas, con un millar de dialectos y las numerosas lenguas llegadas de África desde la tercera década del siglo supusieron complejos intercambios verbales (y no verbales) de los que solo una parte mínima se trasladó a la escritura.

Si la intensidad de Don Quijote (no en vano Cervantes vivía en Sevilla cuando llegaban los hidalgos derrotados en sus sueños) nace de la conversación interminable a lo largo del camino, no puede decirse menos de los escritos sobre América. Los protagonistas se hacen señas, gritan, no entienden nada, entienden al revés, creen entender, suponen, conjeturan, caminan kilómetros: once mil kilómetros caminó Álvar Núñez Cabeza de Vaca por lo que sería casi en esos años el Virreinato de Nueva España, después México.

Desde el primer momento, las prácticas lingüísticas o culturales estuvieron contaminadas por las formas del ejercicio del poder (Chartier, 1992: 61) sobre las que luego se construyeron los aparatos administrativos, políticos y judiciales. Se podría hacer un «corpus» con los fragmentos donde la traducción («la lengua dijo...», «supimos

\footnotetext{
I Aunque las palabras «españoles» $\mathrm{y}$ «España» sugieren una anticipación, es convencional utilizarlas en este período. La cifra de emigrados a América procede de diversas fuentes, especialmente, de Magnus Mörner, autor del estudio más completo sobre el tema: «Spanish Migration to the New World Prior to 1810: A State of Research Report», en F. Chiapelli et alii, (eds.), First Images of America: The Impact of the New World on the Old, Berkeley: University of California Press, 1976, 2, 738-7-82.
}

por los intérpretes...») se convierte en batallas por el sentido, batallas singulares porque el sentido estaba previamente definido. Rara vez o casi nunca, el indígena (aunque en general siempre es un grupo de indígenas, como una pintura coral en el paisaje) expresa una opinión, deseo o queja. El malestar existe pero se desdobla en otra voz, la del cronista que refiere la tragedia, la catástrofe o la pesadumbre, que vio o que le contaron otros que vieron. Aquel silencio en medio de tanta conversación resulta siglos después ensordecedor.

La historia de la traducción (que vive desde hace más de veinte años una auténtica edad de oro) reúne estudios ejemplares sobre traducciones y mediaciones. En el trabajo presente se interrogarán figuras, modos y momentos que pudieran contribuir a esa historia, a través del siguiente itinerario: Introducción. Cristóbal Colón. Ramón Pané. Los intérpretes como voz de la antropofagia. Leyes de Indias. Comienzos de la traducción en América. La traducción literaria. Control de la lengua y los libros.

\section{CRISTÓBAL COLÓN}

Colón fue el único conquistador del que conocemos su formación²:

Todo lo que fasta hoy se navega lo he andado. Trato y conversación he tenido con gente sabia, eclesiásticos e seglares, latinos y griegos, judíos y moros, y con otros muchos de otras setas. En la marinería me fizo Nuestro Señor abundoso; de astrología me dió lo que abastaba, y ansí de geometría y aritmética, y engenio en el ánina y manos para debujar esfera, y en ella las cibdades, ríos y montañas, islas y puertos, todo en su propio sitio. En este tiempo he yo visto y puesto estudio en ver de todas escrituras, cosmografías, historias, coró-

La palabra «formación» describe los saberes que acumuló más que los estudios sistemáticos (que no tuvo). Sus escritos y en especial El libro de las profecías señalan lecturas $\mathrm{y}$ conocimientos extensos y poco comunes en un navegante. 
nicas y filosofía, y de otras artes, con que me abrió Nuestro Señor el entendimiento con mano palpable a que era hacedero navegar de aquí a las Indias, y me abrió la voluntad para la ejecución dello (Menéndez Pelayo, 1942: 108).

Y del que también conocemos su biblioteca, los libros que anotaba y escritos diversos que conservó la bibliofilia de Hernando Colón, el segundo de sus hijos. También, en cierto modo, es el único conquistador del que conocemos la voz. Su escritura (anterior a las formas retóricas y elegantes que embellecieron las lenguas europeas después del gran ciclo de las traducciones del latín (Highet, 1996: 168-184) tiene la fuerza y la tensión de la pura oralidad. Tanto los diarios de navegación - reconstruidos, aunque no conser$\operatorname{vados}^{3}$-, como otros documentos muestran un diálogo impreciso entre el castellano (la lengua de sus textos), el portugués, formas italianas, el latín y el argot «levantisco», lengua del Mediterráneo usada en el mundo de la navegación (Varela, 1992: XXI). Corresponde también al discurso de la oralidad el desdoblamiento dialógico del Almirante entre lo que cuenta que ve, lo que piensa hacer, lo que hizo, lo que siente, como si leyéramos una representación primitiva de monólogo interior, como si tuviéramos el privilegio de asistir a las formas iniciales de la conciencia moderna sobre las que reflexionó Montaigne.

Así que ayer vino a bordo de la nao una almadía con seis mançebos, y los cinco entraron en la nao; estos

3 Los originales de los relatos de los viajes de Colón se perdieron. Del primer y tercer viaje existen los resúmenes de Bartolomé de las Casas que se conservan en un manuscrito de la Biblioteca Nacional de España. La relación del segundo viaje está tomada de una carta de Colón a los Reyes aparecida en 1992 en el llamado Libro copiador, que se guarda en el Archivo General de Indias de Sevilla. La relación del cuarto viaje se encuentra en un manuscrito, hoy propiedad de la Biblioteca Universitaria de Salamanca, en el que un copista anónimo trasladó la carta que Colón escribió a los Reyes el 7 de julio de 1503 (Colón, 2014: 9-11). mandé detener e los traigo. Y después envié a una casa que es de la parte del río del Poniente, y truxeron siete cabeças de mujeres entre chicas e grandes $\mathrm{y}$ tres niños. Esto hize porque mejor se comportan las hombres en España aviendo mujeres de su tierra que sin ellas, porque ya otras muchas vezes se acaesçió traer hombres de Guinea para que deprendiesen la lengua en Portugal, y después que volvían y pensaban de se aprovechar d' ellos en su tierra por la buena compañía que le habían hecho y dádivas que se les avían dado, en llegando en tierra jamás pareçía(n) otros, no lo hazían así. Así que, teniendo sus mugeres, ternán gana de negociar lo que se les encargare y también estas mugeres mucho enseñarán a los nuestros su lengua, la cual es toda una en todas estas islas de India, y todos se entienden y todas las andan con sus almadías, lo que no han en Guinea, adonde es mill maneras de lenguas que la una no entiende la otra. Esta noche vino a bordo en una almadía el marido de una d' estas mugeres y padre de tres fijos, un macho y dos hembras, y dixo que lo dexase venir con ellos, y a mí me aplogo mucho, y quedan agora todos consolados con él, que deben ser todos parientes, y él es ya hombre de 45 años (Colón, 1992: 56).

En la secuencia (los verbos en cursiva señalan las acciones simultáneas del relato), Colón refiere hechos que ocurrieron (cinco muchachos llegan en una canoa y suben a la nave, manda apresar siete mujeres y sus niños); recuerda haber tomado hombres solos en Guinea que, a la vuelta de Portugal — donde aprendieron el idioma-, no fueron de utilidad; razona que los hombres en España se portan mejor con mujeres de su tierra que sin ellas; cree que los mancebos que lleva serán más útiles por la compañía femenina y que las mujeres «enseñarán» la lengua «a los nuestros»; piensa que la lengua de las Antillas «es toda una» (Génesis 11: 6), no como en África; se compadece del hombre de cuarenta y cinco años [la edad de Colón entonces] que se presenta como marido de alguna de estas mujeres y al que cree pariente de todo el grupo. Parece alguien que está pensan- 
64 do en voz alta, que ve la realidad como signos, los traslitera en comportamientos e infiere los beneficios que se puede obtener. Es verdad. Cualquier análisis de su biografía, por superficial que sea, revela el especial talento del Almirante para las cosas prácticas: ver donde otros no ven. O ver como signos lo que todos ven.

Michele de Cuneo, el italiano que estuvo con Colón en el segundo viaje, elogió enfáticamente que «desde que Génova es Génova, no ha nacido hombre tan esforzado y sabedor del arte de navegar ${ }^{4}$ como el dicho señor Almirante» y describe: «con ver una nube o una estrella de noche juzgaba el cielo que debía venir, y si había de hacer mal tiempo, él en persona dirigía y permanecía al timón. Y una vez que había pasado la tempestad, él largaba las velas y los demás dormían» (Cuneo, 1984: 259).

\subsection{El libro maravilloso de las Indias}

La habilidad para la abducción no oculta, sin embargo, que en gran parte de los escritos de Colón resuenan largamente las conjeturas fantasiosas o las divagaciones mesiánicas. Aunque las figuraciones más significativas, comunicadas por señas, también tuvieron una finalidad práctica.

Los unos nos traían agua, otros otras cosas de comer; otros, cuando veían que yo no curava de ir a tierra, se echaban a la mar nadando y venían y entendíamos que nos preguntavan si éramos venidos del çielo (Colón, 1982: 32). «Dixeron por señas que antes de tres días vernían muchos mercaderes de la tierra adentro a comprar de las cosas que allí llevan los cristianos y darían nuevas del rey de aquellas tierras, el cual, según se pudo entender por las señas que daban, qu'estaba de allí a cuatro

4 También Consuelo Varela y Juan Gil describen a Colón como un extraordinario navegante y recuerdan que la ruta que abrió hacia América fue la usada en los siglos siguientes. jornadas, porque ellos avian enbiado muchos por toda la tierra a le hazer saber del Almirante» (op. cit.: 49). «Entendió también que lexos de allí avia hombres de un ojo y otros con hoçico de perro que comían los hombres, y que en tomando uno lo degollaban y le bevían la sangre y le cortaban su natura» (op.cit.: 51). «D'esta gente diz que los de Cuba o Juana y de todas estas otras islas tienen gran miedo porque diz que comían los hombres. Otras cosas le contaban los dichos indios muy maravillosas» (op.cit.: 72). «(...) Caniba no es otra cosa sino la gente del Gran Can, que deve ser aquí muy vezino, y terná navíos y vernán a captivarlos, y como no vuelven, creen que se los $<$ han $>$ comido. Cada día entendemos más a estos indios y ellos a nosotros, puesto que muchas veces ayan entendido uno por otro, dize el Almirante» (op.cit.: 78). «Holgáronse mucho con los cristianos los indios, y truxéronles ciertas flechas de los de Caniba o de los caníbales [...]. Mostráronles dos hombres que le faltavan algunos pedaços de carne de su cuerpo e hiziéronles entender que los caníbales los avian comido a bocados: el Almirante lo creyó (op.cit.: 84). [Las cursivas son mías].

Una de las pocas lecturas literarias (no bíblicas) que Colón cita literalmente fue la $M_{e d e a^{5}}$

5 En el Libro de las profecías se lee: «Seneca in VII tragetide (sic) Medee in choro» «Vernán los tardos años del mundo ciertos tiempos en los cuales el mar Ocçéano afloxerá los atamentos de las cosas y se abrirá una grande tierra; y un nuebo marinero, como aquel que fue guía de Jasón, que obe nombre Tiphi, descobrirá nuebo mundo y estonçes non será la isla Tille la postrera de las tierras» (Varela 1982, 262). «Durante los últimos años del mundo,/llegará un día en que el océano/aflojará las cadenas, y una enorme masa de tierra/aparecerá; Tifis descubrirá nuevos mundos/y Thule dejará de ser el país más remoto» (Versión modernizada citada en Memorial de los libros naufragados. Hernando Colón y la búsqueda universal (2019) de Edward Wilson-Lee quien afirma que la presencia de Séneca en el Libro de las profecías se debe a una interpolación del propio Hernando que pudo poseer una traducción manuscrita, hoy perdida, de Séneca [págs. 86, 91 y 277]). Más allá de las versiones de Séneca de Alonso de Cartagena no existían todavía traducciones de Medea; obra, sin embargo conocida, quizás en italiano, citada, antes de Colón, por Juan de Mena. 
de Séneca, un estallido antiguo de sangre quizás presente como síntoma y proyección de sus propios temores en la incomunicación con los indígenas, de los que, como observó detalladamente Tzvetan Todorov, el Almirante poco pudo entender. Es probable que como navegante y conversador también conociera los bestiarios medievales y la tradición de lo fantástico que venía del mundo clásico: los hombres con un ojo, los hocicos de perro y los antropófagos.

Y no cabe duda que era lector de la Biblia, más cerca del Tanaj que del Nuevo Testamento al que casi no cita. Las imágenes de hombres bajando del cielo ${ }^{6}$ remiten directamente a Génesis 19: la llanura fértil y paradisíaca que cultivaba Lot antes de la destrucción de Sodoma y Gomorra. Quizás la desnudez de los indígenas (una desilusión para quien esperaba los palacios y los artificios del Gran Khan) haya promovido los recuerdos de espantosas y primitivas lujurias, las hijas vírgenes que Lot pretende entregar a los varones de Sodoma para que no sean violados los hombres venidos del cielo, hijas con las que finalmente se acuesta el propio padre (aunque dormido), todo para evitar la destrucción de las ciudades entregadas a la degeneración y a la sodomía. Significados en cierto modo implícitos en la oposición de figuras que crean los dos mitos de futura y larga posteridad: los conquistadores venidos del cielo frente a los caníbales que comían a los otros a bocados.

Colón no era militar, como Hernán Cortés, cuya escritura es un ejercicio de prosa cortesana, un anticipo de novela picaresca, una voz cons-

6 Colón continuó atribuyendo a los indígenas su propia fantasía de que «son venidos del cielo» en documentos que entonces sólo eran privados. También en la Carta a Santangel (1493) que tuvo extraordinaria e inmediata divulgación: «creían muy firmemente que yo con estos navíos y gente venía del cielo» (Colón, 1982: 142). truida para mostrar bajo la mejor luz al héroe de las Américas, cuyos engaños lo llevaron a la gloria. Una narración que reclamaba un lector construido previamente, para saludar como proezas los engaños a los indígenas, para festejar las alianzas con los enemigos de los que querían conquistar, para identificarse con las trampas. Un lector resumido en las expresiones comunes en castellano «engañar como a un indio» o «hacer el indio». Colón no tenía lectores. Tenía enemigos. Nada importante para un visionario de la publicidad como él: construyó un público atónito y fiel al extremo de que nunca «un descubrimiento geográfico fue celebrado» (Gil, 1984: 25) tan estruendosamente en el mundo. Interés que sobrevivió un largo siglo.

Se debe reconocer que no acertaba en sus pronósticos, confundía aliados y adversarios, las islas con la tierra firma, ni siquiera sabía dónde estaba y fracasó en todo lo que no fue llegar al Nuevo Mundo. Sin embargo, creó un canon del relato sobre América difícil de desmentir. Y, mesiánico y por momentos casi enloquecido, pudo vislumbrar en esos resplandores medievales y alucinados todo el programa verbal y no verbal del siglo $x v$ : hablar por señas, capturar esclavos para que oficiaran de lenguas, mandarlos a la Península a aprender castellano, enviar a Ramón Pané a estudiar los idiomas indígenas.

\section{RAMÓN PANÉ}

El legado taíno - aunque conocido con trescientos años de atraso y a través de traduccionesresplandece todavía en el manuscrito del eremita catalán Ramón Pané, editado por primera vez en 1932. Su autor viajó a América en el impresionante segundo viaje colombino de 1493: 17 barcos (12 carabelas y cinco naos), cerca de dos millares de hombres equipados «con los basti- 
mentos ${ }^{7}$, aparejos de repuesto (...) plantas, semillas y acompañados de animales domésticos, herramientas e implementos necesarios para fundar una colonia minera y agrícola y trasplantar la civilización española a las Indias» (León Guerrero, 2000: 92).

Formaban parte de la expedición los primeros religiosos enviados a América, además de Pané, «dos legos flamencos Juan de la Deule y Juan de Tisín ${ }^{8}$ (o Cosin, según otras fuentes)» (Konetzke, 232) y el religioso del Reino de Aragón, Bernardo Boyl ${ }^{9}$, de la orden franciscana de los Mínimos, al que Francisco de Paula había nombrado vicario en España y el papa Alejandro VI vicario en América, para que ellos (según las instrucciones de los Reyes a Colón) «por mano e industria de los indios que acá llegaron, procure(n) que sean bien

\footnotetext{
7 «La provisión necesaria para comer, del nombre griego $\beta \alpha \sigma \tau \alpha \gamma \mu \alpha, \alpha \tau o \zeta$, sustentaculum, gestamen, por cuanto con el mantenimiento sustentamos el cuerpo» (Covarrubias, 1994). La palabra bastimento aparece con profusión en las crónicas del siglo XVI. Los españoles temían por la falta de provisiones y son numerosas las referencias a la presencia o ausencia de víveres. Existen algunos relatos sobre canibalismo entre los europeos (Schmidel, 1986: 34) y (Nuñez: 1981: 41 y 50-51) y también quedaron registradas las quejas de los indígenas sobre las exigencias interminables de comida de los recién llegados.

8 «Deule y Cosin decidieron (...) viajar a la península Ibérica y embarcar para América. (...) Se los mandó al reino de Granada, donde al arzobispo Talavera organizaba la implantación de la fe católica entre los moriscos. No hablaban árabe y por tanto le fueron de poca utilidad. Al final consiguieron el permiso de embarcar con Colón (...). De la Deule habría muerto entre 1508 y 1511, quizás durante su trabajo misionero en Jamaica. Cosin aparece en 1514 como Protector de los indios al lado de Diego Velázquez, gobernador de Cuba. Posteriormente no existe otro indicio» (Thomas, 1994: 452-453).

9 El sacerdote al que un indígena genuflexo besa la mano en el monumento a Colón erigido con motivo de la Exposición Universal de Barcelona en 1888 y emblema del programa económico de la burguesía catalana de entonces. Acompañan a Boyl otras figuras colombinas: las esculturas del capitán catalán Pere de Margarit y el valenciano Luis de Santángel.
}

informados de las cosas de nuestra Santa Fe, pues ellos sabrán e entenderán ya mucho de nuestra lengua, e procurando de los instruir en ello lo mejor que se pueda» (León Guerrero: 2000, 791).

\subsection{La primera etnografía de América}

El escrito de Pané consta de un breve preámbulo, seguido de veintiséis cortos capítulos (en realidad, veintisiete porque existe un capítulo XXV bis) donde se presenta la cosmogonía de los taínos, algunas de sus historias y numerosas referencias geográficas y léxicas muy interesantes. Fray Ramón «anotó los nombres, funciones y atributos de los dioses taínos y relató lo que los aborígenes pensaban que les sucedía a las almas después de la muerte. Describió las ceremonias de los sacerdotes o behiques y las curaciones que éstos realizaban. Recogió los mitos que le contaron sobre el origen del sol y la luna, la creación del mar y los peces, la aparición del hombre en las islas y la domesticación y aprovechamiento de la yuca. Narró algunos pormenores de la evangelización de la Española y explicó el significado de diversas voces taínas. Y hasta refirió la triste profecía, hecha por un antiguo cacique, de que habría de llegar una gente vestida que asolaría y mataría a sus infelices descendientes» (Pané, 1974: 2).

Se cree que Pané entregó la Relación acerca de las antigüedades de los indios a Colón cuando volvió a La Española en 1498 y que el Almirante la llevó a España al regresar del tercer viaje en 1500. El documento singular llegó a manos de Pietro Martire d'Anghiera (Pedro Mártir de Anglería), el cronista de prosa amenísima de la corte de Isabel I que lo tradujo al latín (su lengua de escritura) y lo publicó en Sevilla en Década primera (Libro IX, capítulos del 4 al 7), inicio de lo que sería De orbe novo de 1516. La relación de Pané también había figurado en Libretto di tutta la navegazione de're de Spagna 
de le isole et territori novamente trovati (1504) di autore anonimo. Traducción, en realidad, de una carta enviada desde España por Angelo Trevisan (secretario del embajador Domenico Pisani) a Domenico Malipiero, en 1501 o 1502, en la que se vertía, en veneciano, la primera década De Orbe novo que Pedro Mártir de Anglería estaba escribiendo (Serafin, 1996: 129).

\subsection{Escritura y desaparición del manuscrito}

También Bartolomé de las Casas conoció el manuscrito e incluyó en el capítulo cxx de su Apologética historia de las Indias (publicada por primera vez en 1909) noticias sobre las creencias religiosas de la Española precedidas de compendiosos capítulos donde se enumeran dioses griegos y romanos dando a los hallazgos de Pané un marco histórico aplastante. Y explica aquí el pedido de Colón a

un catalán que había tomado hábito de ermitaño, fray Ramón, hombre simple y de buena intención, que sabía algo de la lengua de los indios, que inquiriese que todo lo que más pudiese saber de los ritos y religión y antigüedades de las gentes desta isla y las pusiese por escripto.

Este fray Ramón escudriñó lo que pudo, según lo que alcanzó de las lenguas, que fueron tres las que había en esta isla; pero no supo sino la una de una chica provincia que arriba dejimos llamarse Macorix de abajo, y aquélla no perfectamente, y de la universal supo no mucho, como los demás, aunque más que otros, porque ninguno, clérigo, ni fraile, ni seglar, supo ninguna perfectamente dellas sino fue un marinero de Palos o de Moguer, que se llamó Cristóbal Rodríguez ${ }^{10}$, la lengua, y éste no creo que penetró del todo la que supo, que fue la común, puesto que ninguno la supo sino él. Y esto de no

Io Cristóbal Rodríguez, marinero de carabela, de Palos, fue el primer castellano que supo la lengua de los indios (León Guerrero, 2000: 904). saber alguno las lenguas desta isla no fue porque ellas fuesen muy difíciles de aprender, sino porque ninguna persona eclesiástica ni seglar tuvo en aquel tiempo cuidado, chico ni grande, de dar doctrina ni cognoscimiento de Dios a estas gentes, sino sólo de servirse todos dellas, para lo cual no se aprendían más vocablos de las lenguas de "daca pan”, "a las minas", "saca oro", y los que para el servicio y cumplimiento de la voluntad de los españoles eran necesarios (De las Casas, 1967: 634-35).

Por último, Hernando Colón en la excelente historia de su padre, Historia del Almirante - a su vez inédita y perdida - reprodujo la Relación de Ramón Pané en el capítulo LXI de la biografía, obra más cercana a un borrador porque quedó inédita al morir en 1539. Alfonso de Ulloa, prolífico traductor al italiano, tradujo el libro estando preso en una cárcel veneciana donde falleció en 1570. La biografía de Hernando Colón sólo existe en la versión italiana a la que se atribuyen numerosos errores por, quizás, las circunstancias adversas de Ulloa.

A las diferentes «versiones» de la Relación de Pané: el veneciano de Angelo Trevisan, la del Libretto en italiano, el resumen en latín de Anglería, el extracto en castellano de Las Casas, la traducción al italiano de Ulloa, se sumó más tardíamente (1965) el hallazgo de una copia del manuscrito de Historia de la Invención de las Indias de Fernán Pérez de Oliva, donde también se incluía el informe del eremita catalán.

El tránsito entre lenguas en pocos años, la velocidad de los traslados, las versiones manuscritas y perdidas, la edición en una lengua (latín) con pocos lectores en los reinos hispánicos, reflejan el interés enorme que tenía el informe de Pané para cierta élite europea. La tardía publicación en castellano (1932) muestra lo contrario: el cerco que existió en el mundo hispánico para que no se conociera la naturaleza cultural y no salvaje de las civilizaciones americanas. 


\subsection{Desaparición de los taínos}

Nada se supo de los taínos hasta el siglo xx. Vacío epistemológico definitivo por el despoblamiento de las Antillas y la práctica desaparición de la nación taína en la primera década del siglo XVI.

Bernardo Boyl volvió a la Península con el capitán Pedro (Pere) Margarit (ninguno de los dos favoreció con sus opiniones a Colón). No se conoce el destino de Ramón Pané en el vaciamiento vertiginoso de La Española que llegó a narrar Anglería antes de 1516.

Los reyezuelos de la isla, que hasta entonces había pasado la vida en paz y tranquilidad, contentos con lo poco que tenían, al ver que los nuestros habían puesto pie en su suelo natal lo llevaban muy mal y nada ansiaban más que arrojarlos de allí o destruirlos por completo y borrar todo recuerdo de ellos. En efecto, la gente que había acompañado al Prefecto [Colón] en ese viaje, en su mayor parte, salvaje, haragana, a la que todo se le daba un ardite y que buscaba la libertad para sí como fuera, no podía en modo alguno dejar de cometer tropelías, y al raptar a las mujeres de los isleños ante los ojos de sus padres, hermanos y maridos, atentos solo al estupro y la rapiña, había soliviantado los ánimos de todos los naturales» (Anglería, 1984: 78).

Y más adelante añade: «Los isleños padecían un hambre tan grande, que ya habían perecido más de cincuenta mil y (...) morían todos los días en tropel como ovejas de un rebaño enfermo» (Anglería, 1984: 80).

Según los estudios más recientes (2019), de Alexander Koch, Chris Brierley, Mark M. Maslin, Simon L. Lewis, del Reino Unido, «los nativos americanos no habían tenido contacto con los patógenos que trajeron los conquistadores lo que produjo las llamadas epidemias de «suelo virgen». Los indígenas «que no murieron de viruela, murieron a causa de la siguiente ola de influenza, los que sobrevivieron a eso sucumbieron al sarampión. La guerra, el hambre y las atrocidades coloniales hicieron el resto en la Great Dying (Gran Muerte) de las primeras décadas del siglo Xvi: 56 millones de fallecidos, el $10 \%$ de la población mundial de entonces» (Koch, Brierley, Maslin, Lewis, 2019: 20-22).

La misteriosa multiplicación de las muertes recorriendo todo el siglo XVI debió ser para las sociedades americanas más poderosa que la fuerza militar y debió sembrar más pavor. Ausencia de sentido que las derrotas enunciadas en las lenguas de los vencidos convirtieron en silencioso estupor, ese no estar en la historia de los pueblos originarios casi hasta el presente.

\section{LOS INTÉRPRETES COMO VOZ DE LA AN - TROPOFAGIA}

Los intérpretes fueron fundamentales en las misiones de «exploración y de conquista dictadas por imperativos comerciales, la sed de poder y el deseo de apropiarse de nuevos territorios» (Delisle, 256). La ausencia de lenguas era una de las menciones desesperadas de Cristóbal Colón en el diario del primer viaje. En cierto modo, también esa necesidad fue una invención. Los lenguaraces, nahuatlatos o intérpretes se hicieron imprescindibles para los descubrimientos y el lucro: conocer amigos y enemigos, costumbres, peligros, dónde encontrar comida, oro, plata, caminos entre la maleza, qué atajos, qué puertos seguros. Había que hacerlos hablar. Aprehender «los lenguas» pasó a ser una rutina como llevar o conseguir «bastimentos». También fue el arma más poderosa. Las conquistas siempre suceden en la lengua de los vencidos, el poder simbólico de las palabras de Cortés o de Pizarro oídas en el idioma de Monteczuma, Cuitláhuac, Cacamatzin o Atahualpa, tuvo que ser demoníaco, demoledor. 


\section{1. ¿Existía la experiencia de la traducción en América antes de la llegada de los europeos?}

Es tradicional dividir a los intérpretes del siglo XVI en dos categorías: indígenas y españoles. Sin embargo, esa clasificación podría ocultar atributos de unos y otros. Quizás sería mejor diferenciar entre nóveles y expertos. El bilingüismo facilita el aprendizaje de nuevos idiomas y la experiencia de alternarlos prepara para la interpretación. Los viajes entre poblaciones de Mesoamérica o del imperio incaico anteriores a 1492 revelan que debió existir un fluido contacto entre lenguas. Experiencias universales porque la mediación lingüística se presenta, entre las sociedades ágrafas y las que conocieron la escritura, como un modo natural de entenderse.

No existen muchos testimonios de los saberes previos, pero algunos son excepcionales. Ramón Pané (probablemente bilingüe, como sus acompañantes flamencos Juan de la Deule y Juan de Cosin o el propio Bernardo Boyl) refiere su solicitud a Cristóbal Colón cuando le encomienda estudiar la lengua general de La Española: «Deme licencia Vuestra señoría para que vaya conmigo alguno de los de Nahuirey, que después fueron cristianos y sabían ambas lenguas. Lo cual me concedió, y me dijo que llevase conmigo a quien más me agradase. Y Dios por su bondad me dio por compañía al mejor de los indios. Era Guaicabanú, que después fue cristiano y se llamó Juan» (Pané, 1974: 5).

Bilinguismo que también se podría atribuir a Yumbé, el intérprete maya de la bellísima escena de la canoa veneciana que ilumina el relato del cuarto viaje colombino referido por Hernando Colón (Colón, 1892: II, 147-150). Y también es posible imaginar previamente bilingüe a Esteban, el esclavo africano que Álvar Núñez Cabeza de Vaca presenta como «alárabe de Azamor» (Nuñez, 1981: 97) quizás hablante amazigh, la lengua bereber de Azemmour, entonces en una colonia portuguesa. También eran previamente bilingües la Malinche (tabasco, náhuatl) y Felipillo, el intérprete de Pizarro en la famosa escena de Cajamarca, nacido en el norte del actual Perú, hablante de una lengua de la familia tallánsechura a la que después sumó el quechua.

\subsection{Para que aprendan hablar}

Aunque no se conocen los criterios, los deseos de Colón de «haber lengua» tuvieron el correlato de secuestrar personas, en su caso hombres, que, por alguna razón, le parecían idóneos como intérpretes. La idea incluía el viaje a Castilla para que aprendieran el idioma e hicieran de lenguas al regresar. También Jacques Cartier (1491-1557) el primer navegante francés en América se apoderó en 1534 de dos nativos iroqueses: Dom Agaya y Taignoagny (Delisle, 1977: 256) para que aprendieran el idioma en su patria y lo ayudaran al volver. Estas prácticas eran frecuentes entre los mercaderes que recorrían las costas africanas, que Colón había conocido en Guinea, como él mismo menciona en sus escritos. Diego Colón, el lengua del que se habla a continuación, sería un ejemplo de estos viajes lingüísticos. También Felipillo, el intérprete de Francisco Pizarro, habría estado dos años (1528-1530) en España, antes de volver al Perú. Quizá existía la esperanza añadida de que al regreso fueran propagandistas de lo que vieron.

Direis a Sus Altezas que, a cabsa que acá no ay lengua por medio de la cual a esta gente se pueda dar a entender nuestra santa fe, como Sus Altezas desean e aun los que acá estamos, como quier que se trabajará cuanto pudieren, se enbia de presente con estos navíos así de los caníbales, ombres e mujeres e niños e niñas, los cuales Sus Altezas pueden mandar poner en poder de personas con quien puedan mejor aprender la lengua, exercitándoles en cosas de servicio, e poco a poco mandando a poner en ellos algún más cuidado que en otros esclavos, para que deprendan unos de otros, que non se 
fablen ni se vean sino muy tarde, que más prefetamente deprenderán allá que non acá, e serán muchos mejores intérpretes, como quier que acá no se dexará de fazer lo que se pueda (Colón, 1982, 153).

El fragmento alude al viaje de Antonio de Torres, en 1494, cuando volvió a España con un número importante de barcos y viajeros del segundo viaje colombino (1493), entre ellos quinientos hombres, mujeres y niños que se embarcaron, contra su voluntad (Cuneo, 1984: 257) en las Antillas y de los que trescientos sobrevivieron a la travesía. Se sabe que fueron vendidos en el mercado de esclavos de Andalucía, luego recuperados, después unos cincuenta entregados al trabajo de las galeras, aunque sólo como préstamo (Mira: 2007, 928). Sin embargo, un grupo de nueve, llamados «nueve cabezas» fueron encomendados al obispo de Badajoz, para que familias de su entorno le enseñaran castellano:

Asimismo el dicho Juanoto [Berardi] dice quel Almirante D. Cristóbal Colon le envió nueve cabezas de Indios para que los diese á algunas personas para que aprendiesen la lengua; y pues estas nueve cabezas no son para vender salvo para aprender la lengua, vos mandamos que se las fagais entregar luego para que faga delios lo que él dicho Almirante le escribió». Carta de los Reyes al naviero Juanoto Berardi del 2 de junio de 1495 (Navarrete, 1859: 198-199).

La documentación al respecto no precisa si se entregaron o qué pasó con ellos.

\subsection{Diego Colón, el lengua}

No sucedió lo mismo con el primer grupo de indígenas que llegó a la Península en el tornaviaje de Colón de febrero de 1493. Gonzalo Fernández de Oviedo los menciona de vuelta en América e identifica a uno de esos jóvenes, Diego Colón o Colom, encargado de explicar, en castellano, la destrucción del fuerte La Navidad que habían dejado en La Española.

Usando de sus ultrajes de tal manera, que los indios no lo podiendo ya comportar, é durmiendo unos é otros descuidados, dexando las armas, ó quando aparejo se fallaba, á todos les dieron muerte, sin que ninguno dellos quedasse. E como el almirante volvia consigo algunos de los indios que avia llevado á España, entre ellos uno que se llamaba Diego Colom, é avia mejor que los otros aprendido é hablaba ya medianamente la lengua nuestra; por su interpretaçion el Almirante fue muy enteramente informado de muchos indios y del proprio rey Goacanagari, de cómo avia pasado lo que es dicho, mostrando este caçique mucho pesar de ello (Oviedo, 1851:48).

También se refiere a este Diego Colón, Pedro Mártir de Anglería que cuenta el mismo episodio (aunque con la ausencia del intérprete), otros posteriores, incluyendo la «transcripción literal» de una conmovedora reflexión de un anciano de ochenta años, el casamiento arreglado del lengua y el destino de los otros «intérpretes».

Anglería describe los movimientos de población (también Álvar Nuñez Cabeza de Vaca y otros cronistas iniciales) que los etnógrafos e historiadores modernos atribuyeron a la llegada de los europeos (huidas de los pueblos, migraciones, abandono de casas y cultivos) aunque el relato de los «intérpretes» adjudicaba las desbandadas a la presencia errática del «caníbal», sujeto degenerado y metáfora de la barbarie que iba justificar la esclavitud y la guerra.

En el primer viaje, sin ningún tipo de mediación verbal, sólo por señas, los antropófagos ya estaban presentes en la crónica. Según el relato de los ademanes, engordaban niños como si fueran pollos para alimentarse, no comían a las mujeres y eran tan fuertes que diez caníbales podían derrotar a cien soldados bien armados y otros detalles. 


\subsection{El segundo viaje}

En el segundo viaje, cuando las naves de Colón entran por el mar Caribe a la altura de Santa Lucía y recorren la media luna que forma la larga sucesión de islas mayores y menores al sur de Puerto Rico, los «intérpretes» señalan la presencia de «caníbales» (Anglería: 1984: 51), en Galana, [de la que Cuneo, que participa en el mismo viaje, indica que estaba desierta (Cuneo, 1984: 240)], en las cercanías de Guadalupe y la isla Deseada, huyendo con la llegada de los españoles, salvo unas «mujeres cautivas» que, a su vez, también «huyeron en la noche», aunque volvieron acompañadas de «sus maridos caníbales» «a los que atrae la presencia de regalos» (Anglería, 1984: 52) y que después también vuelven a huir en desbandada. También en Antigua, Montserrat y Guadalupe reciben testimonios sobre los antropófagos y jóvenes que piden acompañarlos desesperados, aunque luego también huyen. La interpretación de estos extraordinarios hechos, que Anglería entremezcla con escenas de la tradición de Tito Livio y otros autores clásicos, siempre depende de los intérpretes que los acompañan y que llegan a convertir en caníbales a los indígenas «mansos» por afán de brutal venganza: «les pagan en la misma moneda, pues descuartizan a un caníbal ante los ojos de los demás, lo asan, lo desgarran a rabiosas dentelladas y lo devoran» Todo esto, vuelve a decir Anglería, lo averiguaron «gracias a los intérpretes indios llevados a España en el primer viaje» (Anglería, 1984: 56).

Intérpretes de los que, el propio relato de Anglería, reduce a uno:

Al comienzo de esta isla Española hay un región que llaman los naturales Xamaná; desde allí había zarpado el Prefecto (Colón) a la vuelta del primer viaje con aquellos diez indígenas (...). De ellos sólo quedaba tres con vida, al haber perecido los demás por la mudanza nociva de tierras, clima y alimentación. De esos tres manda soltar a uno, no bien tocó en Santéremo, costa de Xamaná a la que había puesto ese nombre. Los otros dos por la noche se tiran al mar a escondidas y escapan a nado (Anglería, 1984: 56).

Al llegar a La Española, «como no había intérpretes» [en esto Anglería diverge de Oviedo quien narra con lujo de detalles el maltrato a los indígenas y las reyertas entre españoles que terminaron en el asesinato de todos] Colón y sus hombres no pudieron entender la explicación del hermano de Guacanarilo sobre la muerte de los que habían permanecido en el fuerte La Navidad. Explicaciones que divagan sobre la llegada de fuerzas de otros reyes de las islas mayores y autores de la matanza y heridas que no se produjeron y terminan con la fuga de las mujeres indígenas que llevaban consigo en las naves y que escapan nadando (no sin ser perseguidas por sus captores) (Anglería, 1984: 58). Varias jornadas después Anglería presenta por fin a Diego Colón, único intérprete colombino identificado como tal y dedicado al oficio, «joven educado entre los suyos ${ }^{11}$ y cogido en el primer

II No se menciona que el indígena Diego Colón hubiera sido bautizado y, por tanto, hubiera podido recibir ese nombre en el sacramento del bautismo. Por tanto, el nombre de familia (el del hijo legítimo de Colón y heredero del mayorazgo) debe provenir de la costumbre de llamar a los sirvientes, sobre todo a los esclavos, con el nombre y apellido del amo. Juan Gil, en las excelentes notas de su traducción de Pedro Mártir que se citan en este trabajo, aclara que en la edición de las Décadas (incompletas) de 1511, Anglería decía «un tal Colón educado entre los suyos desde la infancia» y que en las ediciones de 1516 y 1530 se omite este «desde la infancia» Aunque la explicación de Anglería sí vuelve a aparecer cuando Pedro Mártir relata la entrega de la hermana de Guarionexio como mujer de Diego Colón para calmar los ánimos alterados entre los indígenas, en una de las tantas uniones forzadas de los conquistadores entre los conquistados. Obviamente, Diego Colón no pudo ser educado desde la infancia por la familia del Almirante, aunque debió llegar a España casi niño. 
72 viaje de una isla cercana a Cuba llamada Guanahaní» (Anglería, 1984: 56). En ese recorrido, por Jamaica y Cuba, llegan a una isla fertilísima donde «los indígenas se agolpaban en las naves trayendo pan, algodón, conejos y aves [preguntando] con maravilloso amor al intérprete si esa gente descendía del cielo» (Anglería, 1984: 70). En la isla siguiente, con habitantes menos crédulos «no se pudo coger a nadie, pues a la llegada de los nuestros todos, hombres y mujeres, se dieron a la fuga» (Anglería, 1984: 70).

\subsection{El lector de san Agustín}

Contradiciendo el horror y la vulgaridad del relato de las dentelladas de los nativos y entre la belleza de las playas cubiertas de tortugas, bandadas de grullas y perdices fragantes que comen flores, emerge un octogenario con una cesta con frutas que, digiriéndose a Colón, pronuncia (traducidas por Diego Colón) estas palabras entre las que se cita, asombrosamente, a san Agustín en sus alegatos contra los maniqueos y las dos almas:

Ha llegado a nuestra noticia que has recorrido con poderosa hueste todas estas tierras para ti antes desconocidas, y que has inspirado no pequeño temor a los pueblos que las habitan. Por tanto, te exhorto y te invito a saber que las almas, cuando salen del cuerpo, tienen dos caminos, uno tenebroso y lóbrego, destinado a los que causaron molestia y daño al género humano, y otro placentero y deleitoso, dispuesto para quien les amaron en vida la paz y la quietud de los pueblos. Así, pues, si consideras que eres hombre mortal y que a cada uno le está destinada una recompensa en el futuro según sus obras presentes, no inferirás agravio a nadie (Anglería, 1984: 76).

La exhortación, que anticipa a don Quijote final, sus discursos y hasta la mención (más adelante) de que «para ellos no existía ni mío ni tuyo, semillero de tantos males» (Anglería, 1984: 77), tiene una respuesta del Almirante, también paródicamente caballeresca, « había sido enviado por el Rey y la Reyna de las Españas para pacificar todas aquellas regiones del mundo (...) para vencer y castigar con merecido suplicio a los caníbales y a los demás indígenas malvados, y para proteger y honrar a los inocentes por sus virtudes (...)» (Anglería, 1984: 77).

El examen (que hemos querido minucioso) de la relativa invisibilidad de los intérpretes en estos textos iniciales muestra un uso florido de los indígenas: dan de comer, enseñan qué comer, dicen donde hay oro o perlas o «Brasil», el nombre inicial de la cochinilla (Dactylopius coccus) utilísima entonces. También transmiten información sobre aliados y enemigos cruciales para las conquistas por venir. «Aprovecha a los nuestros el odio capital que se tienen entre sí los reyezuelos barbaros, pues para granjearse el favor de los nuestros, por si alguna vez estalla una guerra con sus enemigos vecinos, mitigan su hambre de cuando en cuando con el pan del país» (Anglería 1984: 120).

\subsection{Uso de lo nativo}

Los relatos (nada fáciles de reconstruir por la mediación de voces: Colón, las lecturas del navegante, las reescrituras que incorporó Bartolomé de las Casas, Anglería, las lecturas y su abundante escritorio) definen, con elementos narrativos de un horror primario, una imagen bastante definitiva de la humanidad americana. Aparatos discursivos que fueron, a lo largo del continente, como un manual de uso de lo nativo.

El diálogo infructuoso por señas y ademanes (o meneos, como los que se atribuyen a Malinche, la intérprete de Hernán Cortés), dando apariencia de verdad al simulacro, se convierte en conversación simulada y alternada a veces con auténtica conversación (para Colón «haber lengua» quería decir tener una charla con alguien 
o también hablar por medio de un intérprete o lengua) donde el o la intérprete está de más porque transmite lo que el oyente - hombre, conquistador, europeo- quiere que se sepa. Alguien, el narrador, en las crónicas y relaciones, hubiera podido decir lo mismo. No obstante, la eficacia de esa enunciación reside en que el intérprete aparece en el coloquio como un falso experto, un argumentum ad verecundiam, certificando la invención discursiva. En esas mímicas o diálogos, el indígena no tiene subjetividad, casi se diría que fuera del escenario de la evangelización inicial donde se dibujó un trato con «individuos», uno por uno, su anonimato era garantía de que la atribución de sentido no estaba en disputa. Interrogado siempre por el intérprete - con muy pocas excepciones (Álvar Nuñez Cabeza de Vaca, dijo saber seis lenguas, Pedro Cieza de León, conoció y tradujo del quechua, como Juan de Betanzos) ningún conquistador pudo hablar las lenguas americanas- el indígena sólo podía repetir (según el relato de los cronistas) los dispositivos formales para que la invención se transformara en discurso, materia escrita e imborrable.

Los lenguas de Colón solo erráticamente poseen un nombre. Los intérpretes de Vasco Núñez de Balboa, Pedrarias Dávila, Juan Díaz de Solis, Sebastián Gaboto, Pedro de Mendoza, Pánfilo de Narváez, tampoco dejaron huella. Los siguientes, Malinche y Felipillo, tienen biografía, personalidad y riquezas. Conocidos como traidores, llevaron el ejercicio de la invención hasta el paroxismo. Muy bien estudiados (y largamente debatidos) sólo cabe señalar que la importancia de sus intervenciones en las escenas finales de Moctezuma, Atahualpa o Cuauhtémoc se debe menos al sentido de las palabras que a su sonido: el efecto de siniestra familiaridad que ordenaba (en la lengua de los «vencidos») rendirse, retirarse, desaparecer.
Con el fin de las grandes civilizaciones de América, hacia mediados del siglo XVI, los intérpretes utilitarios dejaron de representarse en los relatos coloniales. Se los nombra en las Leyes de Indias, repertorio de caóticos sueños imperiales y no es difícil imaginarlos como sucede en el dibujo de Felipe Guamán Poma de Ayala, cosificados e irreales, esperando reaparecer, tres siglos más tarde, mezclados en las filas de los ejércitos republicanos de los países independientes que pretendían las tierras enormes que en el continente interminable habían quedado sin descubrir, sin conquistar, sin someter a sus habitantes.

\section{LEYES DE INDIAS}

Las lecturas convenciones de las Leyes de Indias las consideran parte del cuerpo jurídico de un Estado de derecho donde existe el principio de «la ignorancia de la ley no excusa de su cumplimiento», dando por hecho que estas normas se conocían y se cumplían. En realidad, el principio rector hubiera debido ser: «la ignorancia de la ley es excusa de su incumplimiento» porque el noventa por ciento de los americanos no sabían leer; las leyes se escribían en castellano, lengua que no contó con un sistema de enseñanza en América; las leyes no estaban impresas. Y eran interminables: «se ha llegado a decir que las disposiciones de este tipo dictadas tan sólo por las autoridades centrales fueron más de un millón durante todo el período de dominio español en América» (Andrés Santos, 2007: 49).

Antes de 1543, primera impresión de las llamadas Leyes Nuevas de 1542 (importantes porque se elimina - de los papeles- el sistema de encomiendas que no se extinguirá hasta más tarde) la legislación indiana estaba contenida en un cedulario que reunía las disposiciones dispersas por la itinerancia de la Corte y otras razones. La siguiente y demorada impresión fue precedi- 
74 da de un larguísimo proceso de búsqueda de la legislación y de diversos proyectos a cargo de comisiones y juristas — con sumarios y materiales que se perdieron - hasta seleccionar las leyes que formarán el canon de las «leyes de Indias»: sólo el uno por cierto de su posible contenido (el millón virtual de disposiciones se redujo a poco más de seis mil). Apareció así, siglo y medio después de la edición de 1543, la Recopilación de Leyes de los Reynos de las Indias mandadas a imprimir y a publicar por la majestad católica del rey Carlos II (1680). Cuatro tomos divididos en nueve libros con 218 títulos que contienen 6.385 leyes $^{12}$.

\subsection{La reimpresión infinita}

La edición se reimprimió en 1756, 1774, 1841, 1846, 1889, 1943, 1956, 1973, 1987, 1994, 1998, 2018 ${ }^{13}$. Las numerosas reimpresiones de un texto legal del siglo XVII que no tenía difusión cuando estaba vigente, la publicación de 1943, editada por el Consejo de la Hispanidad (1940) nombre cuya semejanza con el Consejo de Indias es evidente (sobre todo porque la reimpresión de 1943 contó con versiones especiales para los gobiernos de los «países hispánicos») sugieren la invención de un beatus ille asombroso en sociedades modernas.

Aquel cuerpo legal contenía disposiciones relativas a los lenguas en el ámbito de la justicia (figuran en el Título xxviIII, Libro II) y se llaman «De los intérpretes» y son quince disposiciones fechadas entre 1529 y 1630 , y firmadas por Carlos V, Felipe II y Felipe III. La primera ley, de 1529, donde todavía se los llama lenguas, se describe a los intérpretes como ayudantes de gobernadores y de la Justicia, y se establece que no pueden

I2 No se incluyeron en esta recopilación «definitiva», entre otras, las reales cédulas relativas a la prohibición y censura de libros (y traducciones) de «tema americano» que se mencionan más adelante.

I3 Datos de la Biblioteca Digital Hispánica de la Biblioteca Nacional de España y otros archivos. pedir ni recibir de los indios, joyas, ropas, mantenimientos. Se recuerda, dice el texto, que los indios sólo tienen estas obligaciones con sus encomenderos. En 1537, (aquí también se los llama naguatlatos) se establece que los indios que no sepan la lengua castellana podrán hacerse acompañar por un «Christiano amigo suyo» (...) para ver si lo que ellos dicen á lo que se les pregunta y pide, es lo mismo que declaran los Intérpretes». Las diez leyes de 1563 conceden a los intérpretes una jerarquía profesional bien definida: se les fija un sueldo: más de doce preguntas, dos tomines; menos de doce, un tomín; tienen días y horarios de trabajo; se determina que en cada Audiencia debe haber cierto número de intérpretes, los que deben «jurar de forma debida que usarán bien y fielmente, declarando é interpretando el negocio y pleyto, que les fuere cometido, clara y abiertamente, sin encubrir, ni añadir cosa alguna, diciendo simplemente el hecho, delito, ó negocio, $\mathrm{y}$ testigos, que se examinaran, sin ser parciales á ninguna de las partes, ni favorecer más á uno, que á otro». La ley de 1583 recuerda que no se cumple con lo anterior y que «muchos son los daños, é inconvenientes que pueden resultar de que los Intérpretes de la lengua de los Indios no sean de la fidelidad, christiandad y bondad que se requiere, por ser el instrumento por donde se ha de hacer justicia, y los Indios son gobernados, y se enmiendan los agravios que reciben». Problema que cuarenta y siete años más tarde no parece haberse subsanado, pero sí olvidado. Así, dice la última ley de 1630: «Nombran los Gobernadores á sus criados por Intérpretes de los Indios, y de no entender la lengua resultan muchos inconvenientes» (Gargatagli, 1992).

\subsection{Prohibido sentarse}

Evolución hacia la nada que sugiere un modo de imaginar la justicia y no de ejercitarla. Una 
descripción contemporánea de la sala de una audiencia impartiendo penas y castigos, en el medio del desamparo, la ilustra Francisco Cervantes de Salazar, en México de 1554. «En el sitio inferior, al cual se baja por unas gradas, hállanse a ambos lados escribanos y procuradores: frente a los oidores están sentados a una mesa el escribano de cámara y el relator: aquel escribiendo los acuerdos, y éste haciendo relación de los asuntos. Detrás hay un enverjado de madera, que divide la sala, a fin de que la gente baja y vulgar no vaya a sentarse con los demás: tras este enverjado están de pie, tanto los que tienen derecho a tomar asiento, pero no quieren tomarle, como los que aun cuando quieran no podrían, porque no gozan de esa preeminencia» (Cervantes de Salazar, 1985: 45).

La gente baja y vulgar — aparecen en otras partes del texto- son los que deben recibir cristiandad y bondad de jueces e intérpretes. Sus expectativas de justicia no podían resultar mejor si, en lugar de indígenas innombrados, eran personas «principales».

Tal fue el caso del proceso al hijo de Nezahualpilli y nieto del poeta y rey Nezahualcóyotl, don Carlos Ometochtzin, señor de Tezcoco, noble, quien, pese a estar bautizado, fue acusado de continuar con el culto de sus antepasados y conservar libros de pinturas [códices encuadernados] y varias especies de amuletos. Esto ocurrió en 1539. Un proceso civil, con intérpretes notables, entre ellos Bernardino de Sahagún, y un acusado inteligente: «¿Quiénes son estos estos [frailes y españoles] que nos deshacen y perturban y viven sobre nosotros y los tenemos a cuestas y nos sojuzgan?» A ellos (el pueblo náhuatl) los apartan de todo lo que les da placer, cuando no obran así los españoles y frailes ni son castigados por ello. «El desenlace de este episodio fue, como se sabe, trágico, Carlos Ometochtzin, señor de Tezcoco, pereció en la hoguera el domingo 30 de noviembre de 1539» (León-Portilla, 1985: 37-38) ${ }^{14}$.

\section{LOS COMIENZOS DE LA TRADUCCIÓN EN AMÉRICA}

Bernardino de Sahagún, es una conjetura, inició los estudios sobre la historia mexicana en 1590 , un año después del proceso y muerte de Ometochtzin. Escribió hasta el final de su vida y, junto con otros religiosos, fue artífice de genuinas y extraordinarias traducciones. Los autores: sabios indígenas, expertos, algo disminuidos en la atribución histórica de «informantes» y sacerdotes como Sahagún, llegados en las primeras décadas del siglo XVI, de las órdenes religiosas reformadas, preparados para el estudio de los idiomas, inolvidables, fervientes, capaces de reunir las ruinas de una «cultura que habrá de morir» (Durán, 1984: XXXVI) y de la que casi no quedarán otros restos.

Entre 1502 y 1566 llegaron a América, en este orden, misioneros franciscanos, dominicos, agustinos, jerónimos, mercedarios y jesuitas. El franciscano Jiménez de Cisneros, confesor de la reina Isabel y, desde 1495, arzobispo de Toledo participó activamente en el traslado a las Antillas de un buen número de religiosos de los que no se conoce la formación lingüística aunque sí unas abultadas cifras de bautismos. Entre esos sacerdotes llegaron tres flamencos de Gante que habían conquistado el favor de Carlos V, como Pedro de Gante, relevante en la evangelización y la nueva cultura de México.

En 1524, viajan y se radican en distintas ciudades mexicanas los llamados «doce apóstoles», entre ellos Toribio de Benavente (Motolinía) y

${ }^{14}$ Proceso criminal del Santo Oficio de la Inquisición y del Fiscal en su nombre contra don Carlos, indio principal de Tezcuco, estudio preliminar de Luis González Obregón, México, Publicaciones del Archivo General de la Nación, 1910. 
76 Martín de la Coruña, grupo que comienza el estudio profundo y sistemático de lenguas americanas, herramienta para una evangelización real de las poblaciones amerindias. En 1528 viajó Andrés del Olmo; en 1529, Bernardino Riveiro, conocido como Bernardino de Sahagún y, en 1554, Jerónimo de Mendieta. Como se reconstruye en una interesante investigación sobre $L a$ tradición gramatical clásica en la Nueva España, en las primeras instituciones educativas y filológicas como el Colegio Santa Cruz de Tlatelolco: «Había muchos universitarios insignes y de gran preparación: Juan Tecto, maestro de teología de la Universidad de París durante catorce años; Juan Focher, doctor en leyes, cánones y teología, gran latinista, reconocido como el mejor teólogo de la Provincia del Santo Evangelio; Juan de Gaona, excelente latino y retórico, razonable griego, muy aceptable predicador $y$, sobre todo, profundísimo teólogo (Mendieta 1596: v, 59), Bernardino de Sahagún, Alonso de Herrera, Juan de San Francisco y Francisco Jiménez, experto en derecho canónico, y desde luego fray Andrés de Olmos, doctor en Derecho Civil por la universidad de Valladolid. Además, a la Provincia de San Pedro y San Pablo, en Michoacán, llegaron también frailes ilustrados (Torquemada 1615: xx, 53), como Jacobo Daciano, que dominaba las lenguas latina, griega y hebrea, o, quien estudió Artes y Teología en la Universidad de Tolosa. Con estos profesores llegó también a la Nueva España la cultura humanística que se desarrollaba en Europa» (Téllez, 2015: 20).

Las enseñanzas a jóvenes mexicanos tenían el correlato de la formación en lenguas americanas de los recién llegados. Todos ellos hablaron y, en muchos casos, escribieron e intentaron describir formalmente las lenguas de trabajo haciendo «artes» $\mathrm{y}$ «vocabularios» (para uso de feligreses y discípulos) de náhuatl, otomí, zapoteco, toto- naco, zoque, tarasco, etcétera. En el Virreinato de la Nueva España, del período inicial, 15241572, quedaron unas 109 obras de esta naturaleza (Ricard: 1986: 122). Es decir, gramáticas y diccionarios, instrumentos de trabajo y estudio que permitían redactar devocionarios, sermonarios, catecismos y traducir (como se verá más adelante) lo que era el canon básico de las lecturas en la evangelización: secciones de los evangelios, de las Epístolas, de las vidas de los santos.

\subsection{Señas y gatos}

El minucioso estudio de los idiomas permitió que la evangelización hablara la lengua de los evangelizados. Sin embargo, para los religiosos que llegaron a América de cierta edad ese aprendizaje estuvo vedado: Jacobo de Testera, también Bartolomé de las Casas. Aunque convencidos de que los sacramentos del catolicismo no se podían administrar sin una preparación religiosa o incluso una somera compresión de su significado, usaron señas y mediaciones no verbales. «Cuenta Muñoz Camargo que (...) para indicar el infierno "señalaban la parte baja de la tierra [y decían que] había fuego, sapos y culebras y, acabando de decir esto, elevaban los ojos al cielo diciendo que un solo Dios estaba arriba, ansí mismo apuntando con la mano, lo cual decían siempre en los mercados”. Naturalmente, los indios nada entendían» [Ricard: 1986: 118].

El lenguaje gestual también fue acompañado de imágenes. En las misiones, los cuadros y la música suplieron el desconocimiento de las lenguas vernáculas.

Algunos usaron un modo de predicar muy provechoso para los indios por ser conforme al uso que ellos tenian de tratar todas sus cosas por pintura. $Y$ era de esta manera. Hacian pintar en un lienzo los artículos de la fe, y en otro los diez mandamientos 
de Dios, y en otro los siete sacramentos, y lo demas que querian de la doctrina cristiana. Y cuando el predicador queria predicar de los mandamientos, colgaban el lienzo de los mandamientos junto á él, á un lado, de manera que con una vara de las que traen los alguaciles pudiese ir señalando, la parte que queria. Y así les iba declarando los mandamientos. Y lo mismo hacia cuando queria predicar de los artículos, colgando el lienzo en que estaban pintados. Y de esta suerte se les declaró clara y distintamente y muy á su modo toda la doctrina cristiana. Y no fuera de poco fruto si en todas las escuelas de los muchachos la tuvieran pintada de esta manera, para que por allí se les imprimiera en sus memorias desde su tierna edad, y no hubiera tanta ignorancia como á veces hay por falta de esto (Mendieta, 1870: 279).

Esos «cuadros» permitieron explicar los rudimentos del catolicismo, el significado del infierno y la salvación. Las más nombrados pertenecieron a Jacobo de Testera que aprovechó enormemente las posibilidades artísticas que encontró en el Nuevo Mundo. También, Fray Luis Caldera, que desconocía el idioma de sus fieles, «iba de pueblo en pueblo con grandes cuadros en que había mandado a pintar los sacramentos, el catecismo, el cielo, el infierno y el purgatorio, y aún agregó medios más expresivos y quizá no muy serios, pues para hacer que los indios se formaran una buena idea del infierno preparó una especie de horno, en el cual echó perros, gatos y otros animales, y después le prendió fuego: los gritos y los aullidos de dolor de las pobres bestias infundieron a los indios espectadores un profundo horror (Ricard, 1986: 193).

La escena no era lejana de ciertas dramaturgias medievales igualmente crueles ni inspiraría más terror que las imágenes que participaban del culto en iglesias europeas y que producen, todavía hoy, mucho espanto. El Museo de Unterlinden de Colmar conserva algunos de estos ejemplos: el tríptico de Matthias Grünewald o a las representaciones del maligno que aparecen en los cuadros y catecismos de América. Esas obras inolvidables, no contenían, sin embargo, las sutiles modulaciones y las funciones que tuvo la imagen en América.

\subsection{Pinturas}

Decía Jerónimo de Mendieta: «Y lo mismo usaban algunos que no confiaban de su memoria en las confesiones, para acordarse de sus pecados, llevándolos pintados con sus caracteres (como los que de nosotros se confiesan por escrito); que cierto era una cosa de ver, y para alabar a Dios, las invenciones que para efectos de las cosas de su salvación buscaban y usaban» (Mendieta, 1870: 84). Pintados, pinturas, fueron las formas de nombrar las representaciones pictógráficas donde imágenes, colores, formas geométricas, tamaños y gestos eran significantes tan precisos como las letras.

En Mesoamérica la escritura prehispánica tuvo medios propios: papel, colores, formatos en acordeón de las páginas, que desplegadas, permitían lecturas cruzadas y diferentes de lo conocido en Occidente. Los artífices, llamados tlacuilos, por el verbo náhuatl, tlacuiloa, que quiere decir «escribir-pintando», tenían conocimientos profundos de lenguas y de técnicas de representación. Complejidad que no todos podían interpretar y requería una preparación semejante a la del artista. En los códices, los centenares de matices, con diferente valor metafórico o fonético, podían introducir considerables variables de sentido. En todo caso, el número de letrados era significativamente semejante a los alfabetos de la Europa de esos siglos (Galarza, 1990: 33-49).

Códices, mapas, lienzos, catecismos indígenas forman hoy una colección de bellezas (dispersas 
en los Museos y colecciones privadas del mundo) que contienen la historia y los procedimientos plásticos para contar la historia de las culturas americanas. Así como no existen informaciones suficientes sobre las traducciones orales prehispánicas, son numerosos los testimonios del aprovechamiento de las técnicas de las artes gráficas que existían antes de la llegada de los europeos.

Los llamados catecismos dibujados de los que se conservan unos 35 ejemplares de los siglos XVI a XVIII, clasificados por John Glass en 1975, son uno de los mayores ejemplos de ese arte heredado. Conocidos como catecismos testerianos, por Jacobo de Testera que los imaginó e utilizó, contienen en algunos casos imagen y texto (en latín o náhuatl o castellano) y existen interesantísimos estudios sobre cómo interpretar los extraordinarios artefactos. En un catecismo tardío, del siglo XVIII, es posible detenerse en las elecciones de la traducción de un Padre Nuestro del latín al náhuatl atravesando las imágenes pictográficas donde «amén» se traduce por «Que la flor sea», el pan por la tortilla y el demonio por una figura cubierta de cráteres o de ojos (Galarza, 1992: 37).

También los dibujos fueron una de las herramientas del prodigioso trabajo de Bernardino de Sahagún en la Historia general de las cosas de Nueva España, dividida en doce libros, una suma de conocimientos del mundo azteca. La parte conocida como Códice florentino, redactada entre 1578 y 1580 (desaparecida de Roma, aunque era un regalo al Papa Pío V) tiene dos columnas con los textos en náhuatl (la lengua original) que Sahagún después tradujo al castellano y 1800 dibujos sobre medicina, farmacia y plantas. Las enfermedades, los síntomas, los tratamientos, los remedios y las plantas - aunque con diferencias con la medicina europea- no parecen en nada inferiores. François Rabelais, contemporáneo de la cultura azteca, estudió medicina en la Universidad de París, estudios que duraban pocos meses. Todo lo que se sabía entonces sobre el cuerpo y sus problemas cabía en tan escaso tiempo. El conocimiento de la farmacopea americana requería años.

Sahagún contó con la ayuda de especialistas indígenas en todos los campos del saber, copistas, traductores y «editores»: Martín Jacobita, Antonio Valeriano, Alonso Vegerano o Begerano, Diego de Grado, Bonifacio Maximiliano, Mateo Severino, Juan Berardo, Esteban Bravo, Juan Bautista de Contreras.

\subsection{Canciones}

Y el pueblo y los señores de todas partes de la ciudad venían a bailar. Y traían consigo todas sus insignias y lo que habían de llevar a cuestas. Y Juan Martín, Andrés y Francisco también bailaban. Y cuando se vio el Xilanécatl, «baile del estómago inflado por el viento», se supo que era pertenencia de los cordeleros. Y cuando se vio el baile del Tepozpanitl, «el baile de la bandera de cobre», trajeron con él las insignias de Cihuateocaltitlan, del «lugar del templo de las mujeres, y un tocado con plumas de pájaro y dos dalmáticas, una amarilla y otra roja» (León-Portilla, 1985: 59).

El relato corresponde al diario inédito de un indígena llamado Juan Bautista (de Tlatelolco, a mediados del siglo XvI) que participó de una fiesta en honor a San Francisco de Asís, en la que reaparecieron no pocos elementos de la antigua cultura. El manuscrito de Cantares mexicanos, encontrado en la Biblioteca Nacional de México en el siglo XIX, conserva el texto íntegro del Pipilcuicatl «canto de los niños», obra de Pedro de Gante, que se entonaba entonces.

Los Cantares mexicanos que «integran canto, percusión y danza» datan de la segunda mitad del siglo XVI, de las primeras generaciones después de la llegada de los doce franciscanos a Nueva España. Bernardino de Sahagún los reunió en 
forma escrita (en náhuatl), con la ayuda de informantes indígenas. «Los cantares tardarían hasta mediados del siglo $\mathrm{xx}$ para ser traducidos al español y dos décadas más para salir en inglés» (Hankin, 2018). La traducción completa al castellano no se publicó hasta 2016 y ha generado una discusión sobre la naturaleza de estos textos de tan compleja interpretación semiótica, que reclaman una intervención literaria, también antropológica, musical y escénica. Como si se tratara de una escritura pictográfica donde colores, figuras, formas, ondulaciones, construyen una significación compleja en la que todos los elementos son imprescindibles para la interpretación, los cantares también reclaman una traducción plural.

Resulta interesante que esta experiencia de perfomance y sincretismo religioso tuviera como escenario el siglo XVI, fuera parte de la evangelización y careciera casi de relación con la jerarquía de la iglesia. Durante algunos años, en los oficios religiosos de pueblos incluso de veinte habitantes no faltaron los instrumentos musicales: flautas, clarines, cornetines, trompeta real, trombón, flauta morisca, chirimía y atabal. Músicos, cantores y coros produjeron una alegría enorme que el Concilio mexicano de 1555 creyó obligatorio interrumpir. Inmediatamente, una Real cédula de Felipe II de 1561 puso límite a todo regulando, como era habitual, cuántos cantores, clarinetes y coros estaba permitido tener, cuanto debían cobrar los cantantes y lo que no se podía hacer (Ricard, 1986: 285-286).

\section{LA TRADUCCIÓN LITERARIA}

Quizá como en otras lenguas y continentes, la traducción literaria escrita empezó en América con la Biblia. Se trató, desde luego, una traducción pensada desde fuera de la cultura que prestó su lenguaje. Tal es el caso de las Epístolas y Evangelios, traducidos al náhuatl en la déca- da de 1540 por Arnaldo Bassio, Bernardino de Sahagún, Pablo Nazareo y Hernando de Ribas (Téllez, 2019: 146). Encontrados en la Biblioteca Capitular de Toledo (Téllez-Baños, 2018) y cotejados otros documentos (entre ellos la Psalmodia christiana y sermonario de los santos del año de Bernardino de Sahagún) se pudo establecer una familia de textos con diferente función litúrgica de la que formaban parte.

No existen indicios si en los libros doctrinales que circularon por América figuraban traducciones bíblicas de primera mano o, por el contrario, se trataba de versiones en lenguas indígenas de obras de divulgación en castellano de la España de esos años, como, por ejemplo: la obra Epístolas y Evangelios por todo el año, atribuida a Ambrosio Montesino (aunque bastante más remota), uno de cuyos ejemplares fue recogido en el siglo XVI por la Inquisición de México (Matesanz del Barrio, 1997: 216). En este sentido se tienen noticias de diversos libros publicados en México de propósitos semejantes como el «de fray Alonso de Molina, Evangelios de todo el año en lengua mexica, obra a la que alude Mendieta; el de fray Benigno Fernández, Epístolas y Evangelios o el de fray Domingo de Santa María, Doctrina cristiana y Epístolas y Evangelios en lengua mixteca. Todas ellos de fecha desconocida.» (León Azcárate, 2015: 200).

Casi perdidos hoy, fueron la base de las ceremonias litúrgicas en lenguas americanas hasta las prohibiciones de las versiones en vulgar después de los Índices de 1554, 1559 y 1583. En la Psalmodia de Bernardino de Sahagún de la Biblioteca Nacional de España (impresa en México, precisamente, en 1583) se refiere en una interesante nota manuscrita las vicisitudes del volumen y la expresa transgresión que suponía ofrecer versiones bíblicas que no fueran la traducción de la Vulgata, considerada desde el Concilio de Trento (1545 al 1563) la auténtica e inmodificable interpretación. 
En esos años en América no hubo, en ningún caso, una versión completa de la Biblia ni tan siquiera de algunos de sus libros. Quedó, sin embargo, un texto de gran belleza literaria e ilustre posteridad: todavía se encontraba en los misales latinoamericanos bilingües latín-castellano hasta muy entrado el siglo xx (y quizás después). Se trata de Isaías 60:1-6 que, asociado a Mateo 2:1-12 formó el canon bíblico del 6 de enero y una doble epifanía: anunciar el nacimiento de Jesucristo a los gentiles y presentar el descubrimiento de América como una revelación. Colón en el Libro de las profecías (1504) ya había recordado las figuraciones de Isaías porque la escritura en las sombras del profeta auguraba, según la exégesis rabínica, la existencia de un Nuevo Mundo, y también había mencionado (como parte de la predestinación) el breve libro de Abdías en el que aparece el nombre de Sefarad. Más misteriosa que las otras invenciones colombinas mencionadas arriba (el canibalismo de los indígenas caribeños y la noticia de que los conquistadores venían del cielo) las imágenes de Isaías presentadas en náhuatl (y otros idiomas americanos) dieron a la posteridad una prueba poética y arrebatada del nacimiento de un mundo nuevo: «Y andarán las gentes a tu luz, y los reyes al resplandor de tu nacimiento [...]. Alza tus ojos en derredor y mira: todos estos se han juntado, vinieron a ti, tus hijos vendrán de lejos [...] Entonces verás y resplandecerás y se maravillará y ensanchará tu corazón que haya vuelto a ti la multitud del mar [...] ¿Quiénes son estos que vuelan como nubes y como palomas a sus ventanas? [...] Los hijos de los extranjeros edificarán tus muros y sus reyes te servirán [...] No se pondrá jamás tu sol ni menguará tu luna $[. . .]^{15}$.

15 Versión Reina-Varela, Sociedad bíblicas reunidas, 1959, London, New York, págs. 757-758.

\subsection{Traducciones en América del Sur}

El Virreinato del Perú (1542), en tierras del imperio incaico o Tahuantisuyo (conquistado para la corona española en 1532-33) se menciona como escenario de otras traducciones literarias, preliminares curiosos de las prácticas culturales que llegaron después. Por ejemplo, La traduzión del Indio de los tres diálogos de amor de León Hebreo, hecha del italiano en español por Garcilasso Inga de la Vega, natural de la gran Ciudad del Cuzco, cabeza de Reynos y provincias del Pirú, impresa en Madrid en 1591 o la traducción del Canzoniere de Petrarca (Madrid, 1591), con el título Los sonetos y canciones del poeta Francisco Petrarcha que traduzía Henrique Garcés de lengua Toscana en castellana, en la imprenta de Guillermo Drouy. Versión posterior a la que pudo conocer Miguel de Cervantes que la menciona en el «Canto de Calíope» de La Galatea: «De un Enrique Garcés, que al pirüano / reino enriquece, pues con dulce rima, / con sutil, ingeniosa y fácil mano, / a la más ardua empresa en él dio cima, / pues en dulce español al gran toscano / nuevo lenguaje ha dado y nueva estima, / ¿quién será tal que la mayor le quite, / aunque el mismo Petrarca resucite?» (Cervantes, 1980: 898). «[Al portugués Henrique o Enrique Garcés] se le debe, además, la traducción del portugués de Os Lusíadas de Luís de Camões y la versión al castellano De Regno et Regis Institutione de Francesco Patrizi, obra de carácter didáctico, escrita en prosa latina. Después de vivir cuarenta y tres años en el Perú, en 1589, Garcés volvió a España para publicar sus tres obras a sus expensas, ya que la Corona nunca llegó a reconocer sus méritos literarios» (Mancosu, 2012b: 2-3).

No es rara la cita $^{16}$ de Miguel de Cervantes porque solicitó, sin éxito, ser funcionario en tierras

I6 Cervantes cita en el «Canto de Calíope» a otros poetas del Virreinato del Perú: Diego Martínez de Rivera, Alonso Picado, Diego de Aguilar, Pedro de Montesdoca, Vicente Espinel, Juan de Salcedo y varios que no fueron identificados. 
que serían después bolivianas y de las que llegaban noticias fabulosas. Quizás conoció a Garcés o supo de la existencia a pesar de que sus obras tuvieran en la época, como en otros casos de la región, una difusión desigual. Por ejemplo, la Miscelánea antártica de Miguel Cabello de Balboa, escrita en 1586, permaneció manuscrita hasta mediados del siglo XIX, aunque Menéndez Pelayo menciona una traducción al francés de Ternaux-Compans ${ }^{17}$ (Menéndez Pelayo, 1948b: 70). Del Arauco domado (1596) del chileno Pedro de Oña (1596), poema épico con traducciones e imitaciones de la tradición grecolatina, se retiraron dos ediciones (por rencillas personales y celos propios del modo cómo se gestionaron los cargos y la fama en América). También, Diego Mexía de Fernangil que pudo editar la primera parte del Parnaso Antártico (1602) con las traducciones de Ovidio, no conoció impresas las otras partes de su obra que aparecieron varios siglos después.

Mexía, al que Menéndez Pelayo llamó «el más feliz traductor de las Heroidas», tradujo en México, Guatemala y el Perú entre lances diversos para eludir «el fastidio y el molimiento» de las fatigas en América. También Garcés tuvo más de trotamundos que de erudito y hasta el Inca Garcilaso de la Vega «era más de arcabuces y de criar y hazer caballos que de escribir libros». La combinación de genialidad, azar y aventura describen mejor los comienzos de la verdadera vida cultural colonial en América del Sur que no tuvo origen en los letrados sino en personalidades del linaje de Arthur Rimbaud o de Richard Burton que tradujo Las mil y una noches mientras descubría el lago Tanganica. No resulta fácil interpretar en qué medida libros

\footnotetext{
17 Quizás Menéndez Pelayo se refiera a Henri TernauxCompans (1807-1864), historiador, traductor y diputado francés, autor de versiones y catálogos de cronistas y autores españoles en América.
}

publicados en España pudieron influir en la tradición literaria americana, aunque es tradición mencionarlos.

\subsection{Los primeros relatos traducidos de América}

Las otras traducciones precoces de América fueron crónicas o relatos históricos escritos en el siglo XVI, aunque conocidos muy tardíamente. La Crónica Mexicáyotl de Hernando Alvarado Tezozómoc traducida (aunque no literalmente) al castellano como Crónica mexicana y la Historia de la nación chichimeca y Compendio histórico del reino de Texcoco de Fernando de Alva Ixtlixóchitl.

También en el Virreinato del Perú, Pedro Cieza de León redactó una Crónica del Perú de la que se publicó la primera parte en Sevilla en 1553. Más tardías fueron El señorío de los incas (1873) y El descubrimiento y conquista deste reino del Perú (1979) cuyo manuscrito completo fue encontrado en la Biblioteca Vaticana. Como en el caso de Alva Ixtlixóchitl, una parte importante del material fueron traducciones de relatos de los indígenas. Cieza de León se valió de los testimonios orales de los khipukamayuq, intérpretes de khipu (complejo sistema de comunicación incaico) que refirieron historias de su pasado.

Aunque publicada por primera vez en 1880, Juan de Betanzos escribió en 1551 una Suma $y$ narraçión (de los Ingas) que, como indica su título, es un relato ${ }^{18}$ que combina historias orales e incluye, como acontecimiento antropológico, la vida cotidiana. Menéndez Pelayo capturó el mismo matiz en la escritura de Garcilaso de la Vega aunque lo calificó, con notorio sonsonete, más que de historiador, de «folklorista».

I8 Lydia Fossa observa que la palabra «narración» era un neologismo y no figuraba en los diccionarios y vocabularios de la época (Fossa, 1997:2). 
Ya en el siglo XVII aparecen historias, también en el ámbito andino, donde los indígenas, aunque atravesados por la ruptura colonial, tienen su propia voz. Garcilaso de la Vega publicó los Comentarios reales en 1609 y una segunda parte, Historia general del Perú en 1617. A diferencia de las obras de Garcilaso de la Vega, la Nueva Corónicay Buen Gobierno de Guamán Poma de Ayala, quizás intérprete judicial, no se publicó en vida del autor. Eran casi mil doscientas páginas (escritas en castellano con notas en aymará, quechua y otros idiomas), dedicadas retóricamente a Felipe II o III, acompañadas por 398 ilustraciones del texto principal. La Nueva Corónica es un recorrido histórico, la parte llamada Buen Gobierno describe la vida colonial y la necesidad de enmendar errores y agravios, entre ellos los del propio autor que, por diversas injusticias, perdió sus bienes. Uno de los extraordinarios dibujos (que se mencionan arriba) representa «al lengua, la persona que entiende la lengua y hace el borrador, los memoriales para que entienda el letrado», quizá el primer retrato del intérprete en América.

\section{CONTROL DE LA LENGUA Y LOS LIBROS}

En 1553 se ordenó enviar al Consejo de Indias, la Primera y Segunda parte de la Historia de Indias y Conquista de México ${ }^{19}$ de Francisco López de Gómara e incluso después de que muriera el notable historiador personas de confianza investigaron los papeles que podían albergar los archivos del difunto (Reyes: 2000, 181). Las obras de Bartolomé de las Casas también se retiraron de circulación y se prohibió que fueran consultadas sin una licencia especial. En 1556, una Real Cédula firmada por la princesa Juana de Austria, en nombre de Felipe II, mandó - como reveló José

\footnotetext{
I9 La obra no volvió a imprimirse hasta 1729.
}

Toribio Medina ${ }^{20}$ — que «ningun libro que trate de cosas de las dichas nuestras Indias, se imprima ni venda, no teniendo especial licencia nuestra para ello» (Medina: 1958, 6). Esa disposición definió, al menos por dos siglos, la publicación de libros sobre América: se prohibió la impresión y venta sin el control del Consejo de Indias, se recogieron los libros impresos con anterioridad para su examen, se señalaron esos mandatos a impresores y libreros y se establecieron penas muy graves a los transgresores (Reyes: 2000, 189). Las dificultades para controlar de modo eficaz la información fue una de las razones por las que se creó el cargo oficial de Cronista Mayor de Indias en 1571, encargado de redactar la historia oficial de América. Y cuyas funciones se detallan en otra Real Cédula de Felipe II de 1572, porque su cometido no abarcaba sólo recopilar lo escrito, también indagar en archivos, oficios y escribanías lo publicado desde el descubrimiento, incluyendo ritos, costumbres de los habitantes, descripción y riquezas de la naturaleza (Medina: 1958, 35). Ejemplo del rigor empleado fueran las restricciones que afectaron a las investigaciones de Bernardino de Sahagún, cuyos originales (prohibidos expresamente en 1577), se secuestraron y diseminaron por diversos conventos.

También, antes, el Concilio de 1555 consideró peligroso casi todo lo que se venía traduciendo o escribiendo en lenguas indígenas y muchas acciones intentaron paralizar estos trabajos. En 1559, la inclusión en el Índice de biblias y obras religiosas en romance, provocó la desaparición o un escrutinio exhaustivo de lo publicado ante el temor de que contuvieran palabras o ideas que

${ }^{20}$ Las investigaciones del estudioso y bibliógrafo chileno en el Archivo de Indias en las postrimerías del siglo XIX revelaron, entre otros materiales desconocidos sobre imprentas, libros, ediciones y traducciones, las órdenes relativas a prohibiciones y censuras por parte de la corona española y otras instituciones a lo largo del período colonial. 
no correspondieran a las creencias oficiales. Por ejemplo, se retiraron de circulación unos Diálogos de la doctrina cristiana en lengua tarasca en los que luego se vio que no había nada que corregir, aunque dieron lugar a un proceso que duró veinte años. O se llegó a la obsesión de controlar la «literatura de mano», nombre excesivo para la escritura manuscrita que, por su propia naturaleza, escapaba a los controles establecidos. En 1577, una traducción del Eclesiastés «a una lengua india», según la Inquisición, motivó que se supervisaran numerosas obras semejantes y que, al fin, se terminaran prohibiendo todas las traducciones bíblicas a las lenguas amerindias. En 1580 se condescendió a que los sacerdotes tuvieran esos materiales siempre que a los indígenas no les llegara más que el catecismo, objeto también de severos controles. (González Rodríguez, 1997: 40).

Algunos de los nombres del siglo XVI, autores de las «artes» y «vocabularios», traducciones y trabajos de valor incalculable para la filología de lenguas amerindias y el conocimiento de países americanos vieron que sus obras desaparecían, se eliminaban o no se editaban. La nómina de obras publicadas trescientos años después de su escritura es bastante extensa. Como en el caso de Ramón Pané, no se permitió a los contemporáneos conocer el carácter cultural y complejo de las civilizaciones del Nuevo Mundo.

Existió una razón poderosa para que esta censura ocurriera. La conquista de América produjo la sospecha de una agitación exterior (la atribuida envidia de otros países) y un debate interno (que se terminó prohibiendo) en el que se cuestionaron las Bulas de Alejandro VI, único título de propiedad que poseía la monarquía hispánica de las tierras descubiertas por Cristóbal Colón. Los remotos argumentos del derecho romano o de la escolástica tomista esgrimidos por Francisco de Vitoria describieron los dos cuernos del dilema: los amerindios eran salvajes y vivían en un estado de naturaleza (lo que facilitaba cualquier despojo) o, por el contrario, tenían dominio de sí mismos y de sus bienes y poseían creencias, gobiernos, leyes e instituciones preexistentes. La censura de las obras de «tema americano» revela que se hizo lo imposible por ocultar lo segundo para sostener lo primero: para desposeer legalmente al bárbaro hubo que construir previamente su barbarie. (Pagden: 1991, 34-44). Tirados por los campos quedaron los restos de arte precolombino que no llegaron a los museos de arte de Europa, sobre todo a los de España: no hubo nunca colecciones americanas en el museo del Prado. Tampoco «las opacas, incoherentes y misteriosas tradiciones de gentes bárbaras o degeneradas (...) menos familiares y menos interesantes que las de los asirios, los persas o los egipcios» (Menéndez Pelayo: 1948: 10) escaparon de los archivos para ocupar un lugar en la tradición poética, en la imaginación literaria. Los sótanos (o lugares más remotos) del Consejo de Indias se fueron llenando de investigaciones y traducciones que revelaban formas y tradiciones médicas, conocimientos matemáticos y astronómicos, formas de vida social y económica en absoluto desdeñables en la Europa del siglo XVI e imprescindibles para reconstruir la historia perdida del continente. La nómina de las obras que ocultaron la traducción de América hasta la modernidad es un work in progress no siempre completo.

Fernando de Alva Ixtlixóchitl (1568-1648): Historia de la nación chichimeca, Compedio histórico del reino de Texcoco; Hernando Álvarado Tezozómoc (1520?-1610): Crónica Mexicáyotl / Crónica mexicana; Juan de Betanzos (1510-1576): Suma y narración de los Incas (1551), publicada en 1880; Bartolomé de las Casas (1484-1566): Historia de las Indias se publicó en 1875 y 1876, Apologética historia sumaria (de las Indias), en 1909; Pedro Cieza de León (1518-1548): las partes segunda y tercera de su Crónica del Perú se publicaron en 1873 y 1979; 
Bernabé Cobo (1580-1657): su Historia del Nuevo Mundo se publicó entre 1890 y 1893; Diego Durán (1537-1587) su Historia de las Indias e islas de la Tierra Firme se publicó entre 1887-1890; Gonzalo Fernández de Oviedo (1478-1557) su Historia generaly natural de las Indias se publicó completa en 1851 y 1855; Martín de Jesús (m.1568): Relación de Michoacán (se perdió); Francisco Diego de Landa (1524-1579) su Relación de las cosas de Yucatán apareció en 1864; Jerónimo de Mendieta (15251604): Historia eclesiástica indiana (1870); Toribio de Benavente Motonilia f(1490-1569) su Historia de los indios de Nueva España apareció entre 1848 y 1903); Felipe Guamán Poma de Ayala (15341615), su Nueva coronica y buen gobierno vio la luz en 1936; Bernardino de Sahagún (1499-1590) su Historia de las cosas de Nueva España apareció en las postrimerías del siglo XIX y hubo que esperar al siglo Xx para tener una edición completa $\mathrm{y}$ cuidada, la Inquisición destruyó los ejemplares de Pláticas; Pedro Sarmiento de Gamboa (15321592): su Historia indica apareció en 1893; Titu Cusi Yupanqui (1529-1571): la Instrucción o relación de la conquista del Perú no se conoció hasta 1916; el Popol Vuh, recuperado por el padre Francisco Ximénez, apareció en 1857. Por fin, la Relación de la Nueva España de Alonso de Zorita de 1585 no se publicó hasta el año 2000.

\section{REFERENCIAS}

AdoRno, Rolena (1991): Guamán Poma: Literatura de resistencia en el Perú Colonial, México: Siglo XXI.

Alonso Araguás, Icíar (2012): «Negociar en tiempos de guerra: viajes de ida y vuelta entre España y América (ss. XV-XVII)», en Gertrudis Payás y Jose Manuel Zabala Cepeda (eds.), La mediación lingüistico-cultural en tiempos de guerra: cruce de miradas desde España y América, Temuco: Universidad Católica de Temuco, 37-64.

Alonso Araguás, Icíar y Jesús Baigorri Jalón (2004): «Iconography of Interpreters in the Conquest of the Americas», Taduction, Terminologie, Rédaction 17/1, 129-153, <http://www.erudit.org/revue/ TTR/2004/v17/n1/011976ar.html>. [Consultado el 11 de octubre de 2020].

ANDRÉs SANTOS, Francisco José (2007): «Los proyectos de recopilación del derecho indiano en época de Felipe IV», Anuario da Facultade de Dereito da Universidade de A Coruña, 11, 45-69.

AngleríA, Pedro Martir de (1984): Cartas de particulares a Colón y relaciones coetáneas, trad. Juan Gil, Madrid: Alianza.

ArenciBia, Lourdes (1993): «Apuntes para una historia de la traducción en Cuba», Livius, 3, 1-17. $<$ http://scielo.sld.cu/scielo.php?script=sci_arttext \&pid=S1024-94351998000100005>. [Consultado el 21 de octubre de 2020].

BETANZOs, Juan de (1880): Suma y narración de los incas, Tomo 5, Madrid: Biblioteca Hispano-Ultramarina.

BoIDIN, Capucine, Graciela Chamorro y Géraldine Méret (2014): «Fuentes en lenguas amerindias de América del Sur», Corpus, 4/2, <http://journals. openedition.org/corpusarchivos/1335>. [Consultado el 9 de octubre de 2020].

Bowen, Margareta (1995): «Interpreters and the Making of History» en Jean Delisle y Judith Woodsworth (eds.), Translators through History, Ámsterdam: John Benjamins, 245-277.

CASAS, Bartolomé de las (1967): Apologética historia sumaria, México: Universidad Nacional Autónoma de México.

CASAS, Bartolomé de las (1986): Historia de las Indias, Caracas: Biblioteca Ayacucho.

CASAS, Bartolomé de las (1991): Brevísima relación de la destrucción de las Indias, Madrid: Cátedra.

CATElli, Nora y Marietta Gargatagli (1998): El tabaco que fumaba Plinio. Escenas de la traducción en España y América: relatos, leyes y reflexiones sobre los otros, Barcelona: Ediciones del Serbal.

Cervantes, Miguel de (1980): Obras completas, Madrid: Aguilar.

Cervantes de Salazar, Francisco (1985): México en 1554 y Túmulo Imperial, México: Porrúa.

CHARTIER, Roger (1992): El mundo como representación. Historia cultural: entre práctica y representación, trad. Claudia Ferrari, Barcelona: Gedisa. 
Cieza de León, Pedro (2005): Crónica del Perú. El señorío de los incas, Caracas: Biblioteca Ayacucho.

CoLón, Cristóbal (2014): Los cuatros viajes. Testamento, Madrid: Alianza.

Colón, Cristóbal (1982): Textos y documentos completos, Madrid: Alianza.

Colón, Hernando (1892): Historia del Almirante don Cristóbal Colón en la cual se da particulary verdadera relación de su vida y de sus hechos, Madrid: Tomás Minuesa.

CoRTÉs, Hernán (2000): Cartas de relación, Madrid: Dastin.

Covarrubias orozCo, Sebastián de (1991): Tesoro de la lengua castellana o española, Madrid: Castalia.

Cuneo, Michele de (1984): Cartas de particulares a Colón y relaciones coetáneas, Madrid: Alianza.

Delisle, Jean y Judith Woodsworth (eds) (1995): Les traducteurs dans l'histoire, Ottawa: Presses de l'Université d'Ottawa.

Durán, Diego (1984): Historia de las Indias de Nueva España e Islas de la Tierra Firme, México: Porrúa.

FeIERstein, Liliana Ruth y Vera Elisabeth Gerling (eds) (2008): Traducción y poder: Sobre marginales, infieles, hermeneutas y exiliados, Madrid-Fráncfort: Vervuet Iberoamericana.

Fernández de Navarrete, Martín (1859): Colección de los viajes $y$ descubrimientos que hicieron por mar los españoles, Tomo II, Madrid: Imprenta Nacional.

FERNÁNDEZ de Oviedo, Gonzalo (1851) Historia generaly natural de las Indias, Parte I, Madrid: Real Academia de la Historia.

FossA, Lydia (1997): «La Suma y narración... de Betanzos: cuando la letra hispana representa la voz quechua», Guadalajara: Conferencia de la Latin American Studies Association (LASA) <biblioteca.clacso. edu.ar/ar/libros/lasa97/fossa.pdf>. [Consultado el 6 de octubre de 2020].

FossA, Lydia (1992): «Los "lenguas": interpretación consecutiva en el siglo XVI», Boletín de la Asociación de traductores egresados de la Universidad Ricardo Palma Lima 4, 11-12.

FossA, Lydia (2005): «Juan de Betanzos, the Man who Boasted Being a Translator», Meta 50(3), 906-933. <https://www.erudit.org/fr/revues/meta/2005v50-n3-meta979/011604ar/>. [Consultado el 6 de octubre de 2020].
Fossa, Lydia (2008):«El difuso perfil de Juan de Betanzos como traductor de lenguas indígenas», TRANS 12, 51-65.

GalarZA, Joaquín (1990): Amatl, amotxtli, el papel, el libro, México: Tava.

GalARZA, Joaquín (1992): Catecismos indígenas. El Pater Noster, México: Tava.

García-Gallo de Diego, Alfonso (1951-52): «La nueva recopilación de las Leyes de Indias de Solórzano», Anuario de Historia del Derecho Español, 21-22, 529-606.

GARCILASO DE LA VEGA, Inca (1986): Comentarios reales, 2 vols., Caracas: Biblioteca Ayacucho.

GARgATAGLI, Marietta (1992): «La traducción de América» en Miquel Edo Julià (ed.) Actes del I congrés internacional sobre Traducció, Bellaterra: UAB, I, 727-741.

GARIBAY, Ángel María (1989): Visión de los vencidos. Relaciones indígenas de la Conquista, México: Universidad Nacional Autónoma de México.

Garibay, Ángel María (1963-1968): Poesía indígena, 3 vols., México: Universidad Autónoma de México.

Garibay, Ángel María (1964): Poesía Náhuatl, México: Universidad Nacional Autónoma de México.

GARIBAY, Ángel María (1953-1954): Historia de la literatura náhuatl, México: Porrúa.

GIL, Juan y Consuelo Varela (1984): Cartas de particulares a Colón y relaciones coetáneas, Madrid: Alianza.

GLANTZ, Margo (2001): La Malinche, sus padresy sus hijos, México: Taurus.

GONZÁLEZ RODRÍGUEZ, Jaime (1997): «Lecturas e ideas en Nueva España», Revista Complutense de Historia de América, 23, <https://revistas.ucm.es/index.php/ RCHA/article/view/RCHA9797110039A>. [Consultado el 9 de octubre de 2020].

Greenblatt, Stephen (2008): Maravillosas posesiones: el asombro ante el Nuevo Mundo, trad. Socorro Jiménez, Barcelona: Marbot.

GruZINSKI, Serge (1991): La colonización de lo imaginario, trad. Jorge Ferreiro Santana, México: Fondo de Cultura Económica.

GruZINSKI, Serge (2002): The Mestizo Mind: The Intellectual Dynamics of Colonization and Globalization. Translated by Deke Dusinberre, New York: Routledge. [Existe versión castellana: El pensamiento mestizo, trad. Enrique Folch, Barcelona: Paidós, 2000]. 
GRUZINSKI, Serge (1995): La guerra de las imágenes, trad. Juan José Utrilla, México: Fondo de Cultura Económica.

Guamán Poma de AYALA, Felipe (1980): Nueva coronicay buen gobierno, 2 vols., Caracas: Biblioteca Ayacucho.

Hankin, Charlie (2018): «Presencia y performance: los cantares mexicanos frente al historicismo», e-Spania. Revue interdisciplinaire d'études hispaniques medievales et modernes, 30/ juin 2018. [En línea] <http://journals.openedition.org/e-spania/28168>; DOI : https://doi.org/10.4000/e-spania.28168.

[Consultado el 21 de septiembre de 2020].

HigheT, Gilbert (1996): La tradición clásica, Influencias griegas y romanas en la cultura occidental, trad. Antonio Alatorre, México: Fondo de Cultura Económica.

JÁuregui, Carlos (2008): Canibalia. Canibalismo, calibanismo, antropofagia cultural y consumo en América Latina, Madrid: Ediciones Iberoamericana.

KосH, Alexander, Chris Brierley, Mark M. Maslin, Simon L. Lewis (2019): «Earth system impacts of the European arrival and Great Dying in the Americas after 1492» Quaternary Science Reviews, 207, 13-36. [La traducción de las citas es mía].

KonetzKe, Richard (1974): América Latina. La época colonial, trad. Pedro Scaron, Madrid: Siglo xxI.

KURZ, Ingrid (1991) «The Interpreter Felipillo and his Role in the Trial of the Inca Ruler Atahualpa», The Jerome Quarterly, 6/4, 3-4 y 11.

León AzCÁrate, Juan Luis (2015): «La Biblia y la evangelización del Nuevo Mundo durante el siglo XVI», Veritas, 32, 195-227.

LEón GUERRERo, María Monserrat (2000): El segundo viaje colombino, Tesis doctoral, Universidad de Valladolid <http://www.cervantesvirtual.com/obra/ el-segundo-viaje-colombino--0/>. [Consultado el 7 de octubre de 2020].

LEÓN-PORTILla, Miguel (1959): Visión de los vencidos, México: Universidad Nacional Autónoma de México.

León-PORTILla, Miguel (1986): Literatura del México antiguo: los textos en lengua náhuatl, Caracas: Biblioteca Ayacucho.

LEÓN-PORTILLA, Miguel (1985): Los franciscanos vistos por el hombre náhuatl, México: Universidad Nacional Autónoma de México.
LeONARD, Irving Alfred (1996): Los libros del Conquistador, trad. Mario Monteforte Toledo, Gonzalo Celorio Morayta y Martí Soler, México: Fondo de Cultura Económica.

Leyes de Indias, Libro II, Título XXIX. De los intérpretes. En 1611. Revista de historia de la traducción. <http:// www.traduccionliteraria.org/1611/esc/america/leyes.htm>.

LienHARD, Martín (2004) «Traducir para dominar. El aparato colonial y la traducción del discurso de los indios y los esclavos africanos», Vasos comunicantes 28, 51-58. <http://revistavasoscomunicantes. blogspot.com.es>.

LockHART, James (1982): El mundo hispanoperuano, 1532-1560, trad. Mariana Mould de Pease, México: Fondo de Cultura Económica.

LOCKHART, James (1992): The Nahuas after the Conquest: A Social and Cultural History of the Indias of Central Mexico, Sixteenth and through Eighteenth Centurias, Stanford: Stanford University Press.

LÓPEZ DE GÓMARA, Francisco (1979a): Historia de la conquista de México, Caracas: Biblioteca Ayacucho.

LÓPEZ DE GÓMARA, Francisco (1979b): Historia general de las Indias y vida de Hernán Cortés, Caracas: Biblioteca Ayacucho.

Mancosu, Paola (2012a): «Os Lusíadas, de Luis de Camões, en la versión de Enrique Garcés (1591)», en la Biblioteca Virtual Miguel de Cervantes, Biblioteca de Traducciones Hispanoamericanas, pp. 1-6.

Mancosu, Paola (2012b): «El Cancionero de F. Petrarca, en la versión de Enrique Garcés (1591)», en la Biblioteca Virtual Miguel de Cervantes, Biblioteca de Traducciones Hispanoamericana, pp. 1-7.

MedinA, José Toribio (1958): Historia de la imprenta en los antiguos dominios españoles de América y Oceanía, Santiago de Chile: Fondo histórico y bibliográfico José Toribio Medina.

Mendieta, Jerónimo de (1870): Historia eclesiástica indiana, México: Antigua Librería, Portal de Agustinos.

MENÉNDEZ PELAyo, Marcelino (1942): Estudios y discursos de crítica histórica y literaria. Escritores históricos, Madrid: CSIC.

MenÉndez Pelayo, Marcelino (1948): Historia de la poesía hispano-americana, I, Madrid: CSIC. 
MenÉndez PElayo, Marcelino (1948): Historia de la poesía hispano-americana, II, Madrid: CSIC.

Mignolo, Walter y Freya Schiwy (2002): «Beyond Dichotomies: Translation/Transculturation and the Colonial Difference» en Elisabeth Mudimbe (ed.) Beyond Dichotomies, Syracuse: Syracuse University Press, 251-286.

Mira Caballos, Esteban (1999): Indios y mestizos en la España del siglo XVI, Madrid: Iberoamericana.

Mira Caballos, Esteban (2007): «Isabel la Católica y el indio americano», en Luis Antonio Ribor García, Julio Valdeón Baruque y Elena Maza Zorrilla, Isabel la Católica y su época: Actas del Congreso Internacional. Valladolid-Barcelona-Granada, 15 a 20 de noviembre de 2004, 2, 921-933.

Motolinía, Toribio de Benavente (1971): Memoriales o Libro de las cosas de Nueva España y de los naturales de ella, México: Universidad Nacional Autónoma de México.

NÚÑEZ CABEZA DE VACA, Álvar (1981): Naufragios y comentarios, Madrid: Espasa-Calpe.

Pagden, Anthony (1991): El imperialismo español y la imaginación política, trad. Montserrat Silió, Barcelona: Planeta.

PANÉ, Ramón (1985): Relación acerca de las antigüedades de los indios, México: Siglo XxI.

PAYÁs, Gertrudis (2005): El papel de la traducción en la construcción de identidades: el caso de la Nueva España (1521-1821), resumen de tesis doctoral, Ottawa: University of Ottawa. <http://www.histal.net/wpcontent/uploads/2011/07/ResumenTesisGertaPayas.pdf>. [Consultado el 16 de octubre de 2020].

PAYÁs, Gertrudis, y Jose Manuel Zabala Cepeda (2012): La mediación lingüístico-cultural en tiempos de guerra: cruce de miradas desde España y América, Temuco: Universidad Católica de Temuco.

RICARD, Robert (1986): La conquista espiritual de México, trad. Ángel María Garibay, México: Fondo de Cultura Económica.

ReYes Gómez, Fermín de los (2000): El libro en España y América. Legislación y censura (siglos XV-XVIII), Madrid: Arco Libros.

Rossi Elgue, Carlos (2019): «Salvajes caníbales en el paraíso. Representaciones iniciales sobre la conquista del Río de la Plata», Pléyade. Revista de humanidades y ciencias sociales, 23. <https://www.scielo.cl/scielo.php?script=sci_art text\&pid=S0719-36962019000100125>. [Consultado el 16 de octubre de 2020].

Ruíz Casanova, José Francisco (2018): Ensayo de una historia de la traducción en España. Madrid, Cátedra.

SAHAGún, Bernardino de (1981): El México antiguo, Caracas: Biblioteca Ayacucho.

Serafin, Silvana (1996): «La conquista americana nell'editoria veneziana dei secoli XVI e XVII» Rassegna Iberistica, No. 56,129-151.

Siracusano, Gabriela, y Agustina Rodríguez RoMERo (2020): Materia americana. El cuerpo de las imágenes americanas (siglo XVI a mediados del XIX), trad. Ian Barnett, Rafaela Gunner, Kit Maude, Rodrigo Molina Zavalía, Saénz Peña, Buenos Aires: Universidad Nacional de Tres de Febrero.

Schmidel, Ulrico (1986): Relatos de la conquista del Rio de la Plata y Paraguay 1534-1554, Madrid: Alianza.

SCHWALleR, Robert C. (ed.) (2012): «A Language of Empire, a Quotidian Tongue: The Uses of Nahuatl in New Spain», Ethnohistory, 59/6.

Téllez Nieto, Heréndira (2015): La tradición gramatical clásica en la Nueva España: estudio y edición crítica del Arte de la lengua mexicana de Fray Andrés de Olmos, Tesis doctoral, Universidad Complutense de Madrid, <https://eprints.ucm.es/33231>. [Consultado el 19 de octubre de 2020].

TÉlLEZ NiETo, Heréndira, y José Miguel Baños Baños, (2018): «Traducciones bíblicas en lenguas indoamericanas: el evangeliario náhuatl de la Biblioteca Capitular de Toledo (mss 35-22 en Revue d'Histoire Ecclésiastique 113-3/4 pp. 656-689. [Consultado el 11 de octubre de 2020].

Téllez NiETo, Heréndira (2019): Hacia una sistematización de los estudios bíblicos en lenguas indígenas del siglo xvi: la fiesta de la Epifanía y sus diversos textos, Etiam 13 (14), 140-177. [Consultado el 17 de agosto de 2020].

Tномаs, Werner (1994): «Misioneros flamencos en América Latina» Revista Espacio, Tiempo y Forma, Serie IV, Historia Moderna, Tomo 7, 451-478.

Todorov, Tzvetan (1989): La Conquista de América. El problema del otro, trad. Flora Botton Burlá, México: Siglo XXI.

TomLinson, Gary (2007): The Singing of the New World: Indigenous Voice in the Era of European Contact, Cambridge (GB): Cambridge University Press. 
88 VARELA, Consuelo (1982): «Prólogo», en Textos y documentos completos de Cristóbal Colón, Madrid: Alianza.

VARELA, Consuelo (2014): «Las conquistas hispanas del siglo xvi: la función de los intérpretes, lenguas y guías», en Legado español en los Estados Unidos. Ciclo de conferencias con motivo de las conmemoraciones históricas de la Nueva España (2013-2015), Madrid: Escuela Diplomática de España, 14-34.

Wilson-LeE, Edward (2019): Memorial de los libros naufragados, trad. María Dolores Ábalos, Barcelona: Ariel. 